\title{
Walking a Tightrope: Are U.S. State and Local Governments on a Fiscally Sustainable Path? Bo Zhao and David Coyne
}

\begin{abstract}
:
This paper develops a new measure of state and local fiscal sustainability called the "trend gap," which is based on socioeconomic and other fundamental factors and removes the shortterm influence of the business cycle. The paper estimates the trend gap and finds that the nationwide per capita trend gap has been on a growing path over the past three decades, a different conclusion than found in previous studies. Social insurance and income maintenance programs have played a major role in the growth of the trend gap, while pension and other post-employment benefits (OPEB) plans have become increasingly important in driving it up. In addition, there are large and growing disparities in the trend gap across states.
\end{abstract}

Keywords: fiscal sustainability, state and local fiscal trends

JEL codes: H4, H7

Bo Zhao is a senior economist in the New England Public Policy Center in the research department of the Federal Reserve Bank of Boston. David Coyne is a graduate student in the department of economics at the University of California, San Diego. The contact author is Bo Zhao, whose email address is bo.zhao@bos.frb.org.

This paper, which may be revised, is available on the web site of the Federal Reserve Bank of Boston at http://www.bostonfed.org/economic/wp/index.htm

The authors would like to thank Katharine Bradbury, Judy Geyer, Yolanda Kodrzycki, Jim Landers, Rick Mattoon, Rebekah McCarty, Santiago M. Pinto, Andrew Reschovsky, Lucie Schmidt, Bob Triest, Jennifer Weiner, Jeff Wenger, and participants at the Federation of Tax Administrators Revenue Estimation \& Tax Research Conference, the Eastern States Legislative Fiscal Officers Association annual conference, the APPAM Fall Research Conference, the NASBO's meeting on Lessons Learned from the Downturn, the Federal Reserve System Committee on Regional Analysis annual conference, the National Tax Association annual conference, and the New England Study Group seminar for their comments and suggestions.

The views expressed in this paper are those of the authors and do not necessarily reflect those of the Federal Reserve Bank of Boston or the Federal Reserve System.

This version: December 2013 


\section{Introduction}

Policymakers, practitioners, researchers, and municipal bond investors alike have become increasingly concerned about the fiscal sustainability of state and local governments in the United States for a number of reasons. First, the rapid growth in health care costs faced by state governments has exceeded the growth of these jurisdictions' revenue growth in recent decades. According to the Henry J. Kaiser Family Foundation, the nominal value of nationwide Medicaid spending grew about 10 percent annually between FY 1990 and 2004. This is much higher than the 6 percent average annual growth rate of nominal state general revenue during the same period. Consequently, Medicaid has replaced elementary and secondary education as the largest state spending category since FY 2009. It accounted for nearly 24 percent of all state expenditures in FY 2011 (National Association of State Budget Officers 2012).

Second, state and local governments face large unfunded pension and other postemployment benefits (OPEB) liabilities. Recent studies estimate that unfunded liabilities nationwide are around $\$ 3$ trillion for state-administered pension plans and $\$ 1$ trillion for state and local OPEB plans (Novy-Marx and Rauh 2009, State Budget Crisis Task Force 2012). These unfunded retirement benefits liabilities create large demands on revenue, potentially straining state and local budgets. Novy-Marx and Rauh (2012) suggest that without policy changes, pension contributions would have to increase to 14.1 percent of state and local governments' total own revenue in order to achieve full funding of public pension systems over the next 30 years. ${ }^{1}$

Failure to achieve state and local fiscal sustainability could have several negative consequences. First, it could shift fiscal burden to future generations of taxpayers, creating intergenerational inequity. Second, state and local governments may have to severely cut back public services at some point in the future in order to balance their budgets. Such a disruption

\footnotetext{
${ }^{1}$ The State Budget Crisis Task Force (2012) identifies four other major threats to state and local fiscal sustainability: federal deficit reduction; narrow, eroding tax bases and volatile tax revenues; local government fiscal stress; and state budget laws and practices.
} 
to public services would harm residents' quality of life and the local business environment. Third, the credit ratings of state and local governments could suffer, driving up their borrowing costs. In an extreme case, a severe lack of fiscal sustainability might induce investors to flee the municipal bond market, threatening the stability of the entire financial system (Cooper and Walsh 2010).

This paper aims to assess state and local fiscal sustainability as it has evolved over the past three decades. It defines state and local fiscal sustainability as the long-term ability of state and local governments to provide public services that the public demands and is willing to pay for. The paper develops a new measure of state and local fiscal sustainability, based on socioeconomic and other fundamental factors, call the "trend gap." It estimates the trend gap, using a panel data model with state and time fixed effects, and removes the short-term influence of the business cycle, using the high-employment budget approach. A larger trend gap indicates that state and local governments have lower long-term ability to raise revenues to meet public service demand and are therefore less fiscally sustainable.

The paper makes several contributions to the literature. First, it clarifies the meaning of state and local fiscal sustainability, which has been unclear to many policymakers and researchers, and then, based on the definition of state and local fiscal sustainability, it develops a theoretical model, which the current literature lacks.

Second, this paper employs an empirical framework that is more consistent with the definition of state and local fiscal sustainability than the ones used in prior research, and as a result of the improved methodology, it finds different results concerning U.S. state and local fiscal sustainability from previous studies. Mahdavi and Westerlund (2011) show that state and local revenues and expenditures were cointegrated from 1961 to 2006 and therefore conclude that state and local governments were fiscally sustainable. However, the cointegration of revenues and expenditures simply proves intertemporally balanced budget and long-term solvency, which is not equivalent to state and local fiscal sustainability (Ward and Dadayan 2009). Other previous studies such as those by the U.S. Government Accountability Office (GAO 2008, 2011, and 2012) directly calculate the balance between actual revenues and actual 
expenditures in past years, which is clearly affected by idiosyncratic factors and business cycles. As a result, the GAO finds no trend in its measures of state and local fiscal balance between 1980 and 2010. Differing from these studies, this paper estimates the trend gap based on socioeconomic and other fundamental factors and removes the short-term influence of business cycles. It is able to show that the nationwide per capita trend gap was on a growing path during the past three decades and that therefore state and local governments in the aggregate were becoming less fiscally sustainable.

Third, this paper, for the first time, uses actuarially required contributions (ARCs) to pension and OPEB plans as a component of the measure of state and local fiscal sustainability. ARCs are the amounts that state and local governments should contribute to their pension and OPEB plans each year to pay for their workers' earned retirement benefits in the current year and to amortize a portion of the unfunded accrued liabilities. Therefore, ARCs can be considered a measure of each year's long-term costs of state and local retirement plans. However, some previous studies consider only actual government contributions and/or the current year's change in unfunded pension liabilities, while other studies simply ignore pension and OPEB costs entirely.

Fourth, for the first time, this paper uses a panel data model with state and time fixed effects to estimate state and local fiscal sustainability. To the best of our knowledge, Mahdavi and Westerlund (2011) is the only other paper that uses state-level panel data to measure state and local fiscal sustainability, but it does not use a fixed-effects model. Other related studies are time-series analyses of either the national aggregate data of the state and local government sector or data of an individual state (GAO 2008, 2011, and 2012; Ulbrich 1997; Dye and Hudspeth 2010).

Finally, this paper examines disparities across regions and across states in the measure of state and local fiscal sustainability and explores factors that help to explain the disparities observed across states. 


\section{The Concept of State and Local Fiscal Sustainability}

A federal government is considered fiscally sustainable if its budget is intertemporally balanced. Therefore, common tests of federal fiscal sustainability examine whether federal revenues and expenditures are cointegrated or whether the ratio of federal debt to national income remains stable or declines in the long term (for example, Croce and Juan-Ramón 2003; Afonso and Rault 2010; Bernanke 2010).

However, this definition and tests of federal fiscal sustainability are of limited use for studying states and localities. First, federal fiscal sustainability is focused on solvency, while solvency is generally not considered a key to state and local fiscal sustainability (Ward and Dadayan 2009). Federal law explicitly prohibits state bankruptcy. Municipal bankruptcies are relatively rare, partly because local governments' access to bankruptcy is rather restricted. ${ }^{2}$ Localities in 35 states need permission from their state government to file for Chapter 9 protection (Gramlich 2011). ${ }^{3}$ Second, state and local governments and the federal government operate under different fiscal rules. All states except Vermont have a constitutional or statutory balanced budget requirement (National Conference of State Legislatures 2010).4 Therefore, unlike the federal government, they cannot have an unbalanced general funds budget for a considerable period of time. State and local governments are also subject to tax and spending limitations, which do not exist at the federal level.

Compared with well-studied federal fiscal sustainability, state and local fiscal sustainability is a relatively new concept, and even its meaning is unclear and open to interpretation. Policymakers and practitioners often treat state and local fiscal sustainability and structural deficit as interchangeable terms. A structural deficit occurs when the amount of funding needed to maintain current services exceeds the revenue generated by the state's current tax system. ${ }^{5}$ However, Ward and Dadayan (2009) argue that state and local fiscal sustainability

\footnotetext{
2 There have been only about 640 municipal filings for bankruptcy in the United States since 1937 (Reid 2012 ).

${ }^{3}$ Georgia explicitly prohibits its municipalities from filing for bankruptcy.

${ }^{4}$ The balanced budget requirement is not uniformly stringent across states and usually applies only to general funds.

5 The calculations of structural deficit are often restricted to general funds over just one or several years.
} 
is a different analytical concept and should be construed more broadly "due to the increasingly visible and chronic nature of state/local fiscal difficulties" (p. 460).

Chapman (2008) defines state and local fiscal sustainability as "the long-run capability of a government to consistently meet its financial responsibilities. It reflects the adequacy of available revenues to ensure the continued provision of the service and capital levels that the public demands" (p. 115). Similarly, the Governmental Accounting Standards Board (GASB 2011) views state and local fiscal sustainability as a government's ability and willingness to generate revenue needed to meet both current service commitments and financial obligations when they come due, without shifting financial burdens to future periods.

We believe that state and local fiscal sustainability should refer to the long-term ability of state and local governments to provide public services that their constituents demand and are willing to pay for. Such ability of state and local governments should be determined by economic, social, demographic, and other fundamental characteristics of each jurisdiction. Because it is a long-term concept, we believe that a measure of state and local fiscal sustainability should focus on fiscal trends and should not reflect the short-term influence of business cycles. ${ }^{6}$ This definition and the interpretation of this definition determine how we theoretically model and empirically measure state and local fiscal sustainability.

\section{Related Empirical Studies}

In spite of strong interest among policymakers, to our knowledge there are few empirical studies that directly measure state and local fiscal sustainability. Using a panel of 47 states from 1961 to 2006, Mahdavi and Westerlund (2011) test whether state and local revenues are cointegrated with state and local expenditures. They find that broader measures of revenues and expenditures are cointegrated, while narrower measures of revenues and expenditures are not. $^{7}$ They also find regional differences, because three regions of the BEA-defined eight regions

${ }^{6}$ We disagree with Chapman (2008), who regards cyclical pressure as one of the major sources preventing fiscal sustainability of state and local governments.

${ }^{7}$ Mahdavi and Westerlund (2011) conduct a cointegration test of four pairs of revenues and expenditures: (1) total revenues versus total expenditures, (2) general revenues versus general expenditures, (3) general revenues versus current expenditures, and (4) own-source general revenues versus current general direct expenditures. By their 
can reject the cointegration hypothesis for the narrowest measure of revenues and expenditures. ${ }^{8}$ They therefore conclude that state and local governments are fiscally sustainable when their budget deficits are broadly defined.

The GAO (2008, 2011, and 2012) focuses on the aggregate state and local operating balance net of funds for capital expenditures, a measure that is intended to gauge "the ability of the (state and local government) sector to cover its current expenditures out of current receipts" (2008, p. 4). Based on the aggregate data of state and local receipts and expenditures, the GAO finds that the state and local operating balance fluctuated narrowly within plus and minus 1 percent of GDP and showed no trend during the 1980-2010 period. Assuming that the current tax structure remains constant, the GAO forecasts that the state and local operating balance as a share of GDP will decrease by about 1 percentage point per decade, mainly because of the rapid growth expected in health-care-related expenditures.

Two other studies focus on individual state governments. Ulbrich (1997) examines the state general funds balance of South Carolina. The report does not analyze past budgets before FY 1997, but forecasts general funds balances for FY 1998-2010, based on simplistic assumptions on income elasticity for revenue, personal income growth, population growth, and the inflation rate.

Dye and Hudspeth (2010) create a so-called "consolidated budget" for the Illinois state government. It includes general funds, the transportation budget, local aid, debt service, health care provider taxes and fees, and federal grants for special purposes. They then develop three measures of the consolidated budget gap. The first measure is the difference between total receipts and total expenditures of the consolidated budget. Total receipts include state borrowing; total expenditures include actual pension contributions and pay-as-you-go OPEB expenditures. The second measure removes new borrowing in the current year from total

definition, cointegration in the first two cases would indicate "weak" sustainability, while cointegration in the other two cases would indicate "strong" sustainability. Their paper cannot reject the null hypothesis of cointegration in the first two cases, but can reject the null hypothesis in the other two cases.

8 The Far West, Great Lakes, and Mideast regions can reject the null hypothesis that their own-source general revenues are cointegrated with their current general direct expenditures. This means that by Mahdavi and Westerlund's definition, these regions do not meet the condition for "strong" sustainability. 
receipts. The third measure adds the change in unfunded pension liabilities in the current year to the second measure. However, it ignores the previous level of unfunded pension liabilities, which the state is still obligated to pay. In addition, due to data limitations, none of the three measures takes into account unfunded OPEB liabilities. Dye and Hudspeth (2010) use historical data to directly calculate these three gap measures for 1997-2009 and then use a regression approach to project future budget gaps. ${ }^{9}$

These previous studies do not measure what we and other scholars define as state and local fiscal sustainability. Mahdavi and Westerlund (2011) is based on the definition and test of federal fiscal sustainability, which the literature generally views as inappropriate for the study of states and localities. Even Mahdavi and Westerlund recognize that "Balancing recorded revenue and expenditure flows is not necessarily an indicator of good fiscal health" (p. 967). The other studies (except Dye and Hudspeth's third measure) essentially measure the structural deficit, which is also a different concept from state and local fiscal sustainability (Ward and Dadayan 2009).

When calculating budget gaps for past years, these studies do not distinguish the gap determined by socioeconomic and other fundamental factors from the gap generated by idiosyncratic factors. They also do not remove short-term influences of business cycles. As a result, their gap measures for past years fluctuate significantly in response to business cycles.

The treatment of pension and OPEB costs in these previous studies is problematic. Some studies include only actual government contributions and/or the current year's change in unfunded pension liabilities, while others simply ignore pension and OPEB costs entirely. In addition, these studies do not define gap measures sufficiently broadly. Some of their measures are limited to general funds or operating budgets and are defined only at the state level,

\footnotetext{
9 They estimate the growth rate of each receipt and expenditure category as a function of economic and demographic characteristics in the regressions. However, because they have a very small sample size of 12 observations, personal income is the only statistically significant explanatory variable in some regressions. Furthermore, when no economic or demographic characteristics are significant in other regressions, Dye and Hudspeth arbitrarily set those receipt and expenditure categories to grow at the same rate as personal income.
} 
ignoring local governments. This paper attempts to contribute an improvement over these previous studies by developing a better measure of state and local fiscal sustainability.

\section{Theory}

Fiscally sustainable state and local governments can raise revenues to provide public services that their constituents demand in the long run. Like any other demand function, state and local services (S) demand is determined by resources available for the jurisdictions (R) and preferences of their constituents (D), such that

$$
S=S(R, D)
$$

To meet such demand, state and local governments produce public services depending on the size of their expenditures (E) and the so-called "environmental costs" (C), such that

$$
S=S(E, C) \text {. }
$$

Bradford, Malt, and Oates (1969), who first introduced environmental costs, point out that, holding all else equal, a jurisdiction with a harsher socioeconomic environment that is outside the direct control of government has to pay more to obtain the same level of public services. The unemployment rate is an example of an environmental cost factor. A higher unemployment rate raises the cost of providing Medicaid because the unemployed are more likely to resort to publicly provided medical care.

Through a standard inversion of the production function, we can derive an expenditure function as

$$
E=E(S, C)
$$

Because the level of public services is often unobservable, we substitute for it with variables that are more easily observable, $R$ and $D$, based on equation (1). As a result, we can rewrite the expenditure function as

$$
E=(R, D, C) \text {. }
$$


State and local governments need to collect sufficient revenue to fund the demanded services. The literature typically models state and local revenues $(\mathrm{T})$ as a function of resources available to state and local governments and their tax policies $(\tau)$, such that

$$
T=T(R, \tau)
$$

Tax policies are endogenous and influenced by available resources and preferences of the constituents in each jurisdiction, ${ }^{10}$ such that

$$
\tau=\tau(R, D)
$$

Therefore, we can substitute for $\tau$ and rewrite the revenue function as ${ }^{11}$

$$
T=T(R, D) \text {. }
$$

Business cycles affect determinants of revenue and expenditure, such as personal income (as a proxy for available resources) and unemployment rates (as an environmental cost factor). As a result, state and local revenues and expenditures fluctuate over business cycles. Unless the impact of business cycles is sustained over the long term, such relatively short-term fluctuations do not reflect changes in the long-term ability of state and local governments to provide public services. ${ }^{12}$ Therefore, a measure of state and local fiscal sustainability should exclude the short-term influence of the business cycle on state and local fiscal conditions.

We adjust available resources and environmental costs $(\hat{R}, \hat{C})$ to remove the short-term effects of business-cycle variations. Thus, we can define the so-called "trend revenue" $\left(T_{L}\right)$ and "trend expenditure" $\left(E_{L}\right)$ as

$$
\begin{aligned}
& T_{L}=T(\hat{R}, D), \\
& E_{L}=(\hat{R}, \hat{C}, D) .
\end{aligned}
$$

\footnotetext{
${ }^{10}$ By treating fiscal policies as endogenous, we indirectly take account of some policy changes over time.

${ }^{11}$ As equations (4) and (7) show, available resources and preferences determine both revenue and expenditure, which reflects the fact that revenue and expenditure are interdependent.

12 An example of the long-term impact of business cycles is that the Great Recession affected the labor market so severely that it raised not only the actual unemployment rate, but also the CBO's estimate of the natural rate of unemployment.
} 
Trend revenue represents the long-term ability of state and local governments to raise their revenues. Trend expenditure represents the state and local spending amount needed to meet public service demand and fulfill these governments' long-term financial obligations. The "trend gap" $\left(G_{L}\right)$ is therefore defined as

$$
G_{L}=E_{L}-T_{L}
$$

Different from the actual budget gap, this trend gap indicates the degree of long-term imbalance between the service demand and the revenue-raising capacity of state and local governments. The larger the trend gap, the lower the long-term ability of state and local governments to provide demanded public services, and therefore the less fiscally sustainable state and local governments.

\section{Econometric Specification and Data}

We estimate the revenue equation (7) and the expenditure equation (4) using a panel data model such that

$$
\begin{aligned}
& \log T_{i, t}=\alpha_{1} R_{i, t}+\beta_{1} D_{i, t}+Z_{i}+Y_{t}+\mu_{i, t}, \\
& \log E_{i, t}=\alpha_{2} R_{i, t}+\beta_{2} D_{i, t}+\gamma_{2} C_{i, t}+Z_{i}+Y_{t}+v_{i, t},
\end{aligned}
$$

where $T$ and $E$ are per capita revenue and expenditure in 2010 dollars, $Z_{i}$ is a vector of state fixed effects, $Y_{t}$ is a vector of year fixed effects, and $\mu_{i, t}$ and $v_{i, t}$ are residual terms. State fixed effects represent state-specific factors that do not change during the sample period, such as each state's fiscal institutions. Year fixed effects represent year-specific factors that are common across states in each year, such as the health care inflation rate.

We obtain revenue and expenditure data for 50 states and Washington, DC, from the U.S. Census Bureau's Annual Survey of State and Local Government Finances from 1980 to $2010 .{ }^{13}$ This survey is the most comprehensive data source on state and local public finances. It

\footnotetext{
13 The Census Bureau did not conduct the Annual Survey of Local Government Finances for 2001 and 2003. Therefore, the data of those two years are missing.
} 
uses a uniform definition of each revenue and expenditure category, providing reasonably comparable data across states and over time.

We use combined state and local revenues or expenditures as dependent variables because combined state and local data are more comparable across states than state-only or local-only data, since different states choose to divide tax authority and service responsibilities between state and local governments differently. Consequently, using combined state and local data allows us to provide a more comprehensive view of subnational fiscal sustainability than using state-only or local-only data. If these were examined separately, some state governments might appear to be more fiscally sustainable than others simply because they choose to shift more service responsibilities to localities or provide less state aid, putting local governments under greater fiscal stress. Therefore, an analysis based on state-only or local-only data could paint a misleading picture of subnational fiscal sustainability.

We examine all categories of state and local revenues and expenditures, which, taken together, are far broader than general funds. The revenue side includes three categories - tax revenues, other own-source revenues, and federal revenue transfers. The other own-source revenue category includes all current charges, miscellaneous revenues, utility and liquor store revenue, and revenue of unemployment compensation and workers' compensation systems.

Among these three revenue categories, tax revenues are the largest revenue source, comprising slightly over half of state and local revenues during the sample period (Table 1). The other own-source revenue category accounts for less than one-third of state and local revenues, while federal revenue transfers make up the remaining 18 percent.

We examine state and local expenditures by their functions, including education, social service and income maintenance (SSIM), public safety, transportation, environment and housing, government administration, interest on general debt, public pensions, OPEB, and other expenditures. Each function includes both its current operations and capital outlays (if any). SSIM covers public welfare, hospitals, health, and social insurance administration (excluding unemployment insurance and workers' compensation). About two-thirds of the 
SSIM expenditures nationally are directly related to Medicaid. ${ }^{14}$ The other expenditures category includes other direct general expenditure, intergovernmental expenditure, utility and liquor store expenditures, as well as expenditure of unemployment compensation and workers' compensation systems. We treat pensions and OPEB independently because they are distinct from other functions and their data come from a different source.

Among the nonpension and nonOPEB expenditure categories, the two largest are education and SSIM. They comprise 31 and 22 percent, respectively, of the nonpension and nonOPEB expenditures. Most of the remaining expenditure categories are small, each making up less than 8 percent of the total, with the exception of other expenditures, which accounts for 16 percent of the total.

In addition to these expenditure categories, state and local governments promise to pay their employees' pension benefits and OPEB (mostly retiree health insurance). We use pension and OPEB ARCs as a proxy measure of state and local governments' true annual retirement costs. The Governmental Accounting Standards Board (GASB) defines ARC as the amount of funding required of government employers to enable them to pay the employers' share of the annual normal cost and to amortize the unfunded accrued liability within no more than 30 years. ${ }^{15}$ The normal cost is defined as the present value of the projected retirement benefits that active employees earn in the current year. ARCs are generally considered to be the amount that state and local governments should contribute to the pension and OPEB plans each year to ensure that these plans can be sustained in the long run.

We use ARC data from 2001 to 2010 obtained from the Pew Center on the States (2010 and 2011). ${ }^{16}$ The data cover the 231 pension plans and 159 OPEB plans, which are the largest such plans in each of the 50 states. The OPEB ARCs of most states are available only since 2008,

\footnotetext{
14 The Census Bureau's data do not include a breakdown of Medicaid spending by state.

15 The data we use do not report the breakdown of the ARC between the normal cost and the amortization payment. The data also do not allow us to know what proportion of the ARC amount is traceable back to each government sector such as education and public safety.

${ }^{16}$ Due to data limitations, our analysis does not reflect pension and OPEB reforms that occurred after 2010. Snell (2012) reports that 43 states increased employee contributions to pension plans and/or reduced pension benefits between 2009 and 2011.
} 
because state and local governments have only recently begun to conduct actuarial valuation of OPEB plans under GASB Statement $45 .{ }^{17}$

We use ARCs instead of actual government contributions as the measure of retirement costs, because state and local governments tend to contribute less than the ARCs to their retirement plans. On average, they paid 86 percent of the pension ARCs from 2001 to 2010 and 34 percent of the OPEB ARCs from 2008 to 2010 (Table 1). Therefore, actual contributions significantly understate the true long-term retirement costs of state and local governments.

However, ARCs still represent a conservative estimate of the true retirement costs of state and local governments. First, state and local governments often choose a higher discount rate than they should to artificially lower their pension liabilities and ARCs. Novy-Marx and Rauh (2009) argue that pension liabilities should be discounted with a risk-free interest rate, because pension benefits are legally protected and therefore considered to be risk-free for public employees. ${ }^{18}$ But in reality, public pension plans widely use an 8 or 8.5 percent discount rate, which is much higher than the risk-free Treasury rate, which usually ranges from 4 to 5 percent (State Budget Crisis Task Force 2012). ${ }^{19}$ Second, the Pew Center's data underreport ARCs at the local level, because the data do not cover small, locally administered plans, which are often more severely underfunded than large, state-administered plans. ${ }^{20}$

\footnotetext{
${ }^{17}$ Nebraska did not report their OPEB ARCs for 2008-2010.

18 The State Budget Crisis Task Force (2012) reports that in 43 states the constitution or statutes guarantee public pension benefits. In comparison, OPEB are often not considered to be as legally binding as pension benefits, because OPEB are contractual in nature and therefore employers may adjust them in a relatively short period. However, a recent California Superior Court decision suggests that state and local governments may not have the flexibility in adjusting OPEB that they previously assumed (Fitch Ratings 2013).

19 The recently adopted GASB Statements 67 and 68 recommend a hybrid discount rate system (GASB 2012). Public pension plans can continue to use a higher rate to discount the portion of benefits that are funded by existing assets, investment income, and contributions, but should use a lower, high-grade municipal bond yield to discount the remaining "unfunded" portion of benefits.

20 The Pew Center on the States (2010 and 2011) reports only the sum of state and select local plans in each state. It does not separate local plans from state plans. A new report by the Pew Center on the States (2013) surveys the FY 2009 pension and OPEB plans of 61 key U.S. cities, which are defined as the most populous city in each state plus all other cities with a population over 500,000. These key cities funded 74 percent of their pension liabilities in FY 2009, which is lower than the 78 percent funded ratio of state pension plans in the same fiscal year. Both states' and these cities' OPEB plans were barely funded, with a funded ratio of 5 and 6 percent, respectively. In addition, these key cities' pension and OPEB ARCs in 2009 amounted to $\$ 13$ and $\$ 72$ billion, respectively.
} 


\section{Regression Results}

Because governments simultaneously make revenue and spending decisions, we use seemingly unrelated regressions to estimate revenue and expenditure equations. We conduct an Engle-Granger residual-based cointegration test and a Westerlund error-correction-based panel cointegration test, both of which show that revenues and expenditures are cointegrated with personal income and that therefore the residual terms of the revenue and expenditure equations are stationary. In addition, we cluster standard errors at the state level to allow for potential correlations within each state over time.

Table 2 shows that personal income positively and significantly determines tax revenue and other own-source revenue. Personal income represents available resources from which state and local governments can collect revenue. ${ }^{21}$ Because both revenue variables and personal income are stated in logarithms, we can interpret the coefficients as income elasticities. ${ }^{22}$ On average, a 1 percent increase in personal income is associated with a 1.2 percent increase in state and local tax revenue. ${ }^{23}$ Other own-source revenue is less income-elastic than tax revenue. Its income elasticity is only about half of the income elasticity for tax revenue. However, neither of the income coefficients differs statistically significantly from 1.

We include educational attainment as a proxy for constituents' preference for the level of taxation and other revenues. ${ }^{24}$ The percentage of the population of age 25 years old or older without a high school degree has a negative and statistically significant impact on both tax

${ }^{21}$ Ladd and Yinger (1989) argue that personal income is the ultimate tax base even for local governments without a local income tax, because all taxes are ultimately paid from income.

22 One might hypothesize that tax revenues respond to changes in personal income differently under different income tax regimes. To test this hypothesis, we included an interaction term of personal income with a dummy variable for multiple state income tax rate brackets. This dummy variable serves as a proxy for progressive income tax systems. While the estimated coefficient on this interaction term is positive, it is small and statistically insignificant. This finding is consistent with Bruce, Fox, and Tuttle (2006), which shows that states with a more progressive income tax system do not necessarily have higher income elasticity.

${ }^{23}$ This estimate is consistent with the work by Bruce, Fox, and Tuttle (2006). They find that the average long-run state personal income tax elasticity is 1.8 , and the average long-run state sales tax elasticity is 0.8 . Our estimate falls in the middle of their estimates because we combine all the tax revenues together.

${ }^{24}$ We explored other variables as potential proxies for preferences, such as whether the state governor is a Democrat, whether the majority of state legislators are Democrats, and whether Democrats control both the governor position and the state legislature. However, none of these variables showed statistical significance when we controlled for state and year fixed effects. 
revenue and other own-source revenue. In contrast, the percentage of the population of age 25 years old or older with at least a bachelor's degree is positively and significantly associated with other own-source revenue. These results suggest that a population with a lower level of educational attainment has a weaker preference for tax and fee increases and the services they support than a more educated population.

We attempt to use economic, social, and demographic characteristics of each state to explain the distribution of federal revenue transfers. However, almost none of the variables is statistically significant when we control for state and year fixed effects. Young (2009) also finds that federal revenue transfers tend to be an unpredictable revenue source, and state and local governments have little or no control in their distribution. Therefore, we do not run a regression analysis of this revenue category. We instead take it as given.

Table 3 shows that personal income is a strong determinant of state and local expenditures. The income coefficients are positive and statistically significant for all the expenditure categories. ${ }^{25}$ This finding is consistent with the fact that wealthier states have more resources to pay for public services. Furthermore, the income coefficients for all service categories, except environmental and housing services, are lower than 1 . This implies that these services are income inelastic and that they are necessary goods for the public. However, only the income coefficients for SSIM, transportation, and other expenditures differ statistically significantly from 1 .

Federal revenue transfers provide additional resources to state and local governments and thus affect state and local spending. The coefficients on federal revenue transfers are positive and significant for almost all spending categories. ${ }^{26}$ These coefficients are significantly below 1, which means that state and local expenditures are not elastic to federal grants. If federal grants increase (or decrease) by 1 percent, each of these expenditure categories will increase (or decrease) by 0.1 to 0.5 percent.

\footnotetext{
25 Our estimates are close to those in the existing literature. For example, our estimated income coefficient for education is 0.760, which is similar to Poterba (1996)'s estimate of 0.672 .

26 The coefficient for education is positive, but surprisingly small and statistically insignificant.
} 
Populations with a different level of educational attainment have different preferences for public services. We find that holding everything else equal, the percentage of the population 25 years of age or older without a high school degree is almost always negatively associated with each spending category. In particular, its coefficient is highly statistically significant for education, public safety, and government administration. In contrast, people with at least a bachelor's degree have a stronger preference for public education, transportation, and other expenditures. ${ }^{27}$

The unemployment rate is an environmental cost factor. ${ }^{28}$ States with a higher unemployment rate need to spend more on SSIM and on the environment and housing, because the unemployed are more likely to resort to Medicaid, low-income housing, and other public welfare assistance. ${ }^{29}$ The unemployment rate is also positive and significant in the regression of other expenditures, likely through its effect on unemployment insurance expenditures, because more workers claim unemployment insurance benefits when the unemployment rate increases. $^{30}$

The age composition of the population is also an environmental cost factor. Holding everything else equal, state and local governments must spend more on public education (mostly elementary and secondary schooling) if the percentage of the population below 18 years

\footnotetext{
${ }^{27}$ Both educational attainment variables are negatively related to public safety and government administration, which suggests that the demand for these public services might be inverse U-shaped in relation to educational attainment.

${ }^{28}$ The unemployment rate may understate the severe impact of the Great Recession on the labor market, because many workers simply dropped out of the labor force and therefore were not counted as the unemployed. The Bureau of Labor Statistics publishes alternative measures of labor underutilization. U-6 is the broadest measure of labor underutilization, which takes account of not only the total number of the unemployed, but also all persons marginally attached to the labor force and the total number of people who are employed part time for economic reasons. However, the state-level U-6 measure is available only since 2003, making the series too short for this analysis.

${ }^{29}$ The state unemployment rate is possibly endogenous because when states cut spending, more workers could become unemployed, which contributes to a higher unemployment rate. However, this would produce a downward bias, pulling our estimates closer to zero.

${ }^{30}$ State and local government spending on unemployment insurance comprises 13 percent of other expenditures. If we excluded unemployment insurance from other expenditures, the unemployment rate would no longer be statistically significant.
} 
of age grows. ${ }^{31}$ On the other hand, these young populations and the elderly populations are less likely to commit or experience crimes than the young adult or middle-aged population. Thus, state and local governments may face less cost pressure on public safety when a higher percentage of their population is younger than 18 or older than 65 years of age. In addition, the coefficient on the percentage of the population younger than 18 years of age is surprisingly negative for SSIM, although it is only marginally significant. This might imply that an additional poor child does not increase social welfare payments as much as an additional poor adult does. ${ }^{32}$

We do not run a regression analysis of interest on general debt for two reasons. First, we are unable to explain interest on general debt using our economic, social, and demographic characteristics of each state while controlling for state and year fixed effects. Second, interest on general debt is largely based on a previous decision to take on debt at the pre-determined borrowing terms. Therefore, we treat interest on general debt as given, which is the same approach that Dye and Hudspeth (2010) use to treat debt interest.

We also do not run a regression for pension and OPEB ARCs. We take them as given because the size of ARCs is largely a result of previous decisions on employers contributions and benefits generosity. We acknowledge that ARCs also depend partly on the history of portfolio returns, which are affected by business cycles. Retirement plans' assets often depreciate in recession years due to bad financial performance, which raises the unfunded liabilities and ARCs. However, retirement plans reduce the cyclical influence on ARCs by

${ }^{31}$ We added the percentage of the population ages 18-24 in an alternative specification. This variable is a proxy for the college-age population, which is a potential environmental cost factor for public higher education. However, the variable is not statistically significant. We also explored the percentage of disabled or special-education students and the percentage of students who qualified for free or reduced-cost school lunches as potential environmental cost factors for education services. We used the Common Core of Data from the U.S. Department of Education's National Center for Education Statistics. However, the data quality is questionable because a large number of states have missing or seemingly incorrect values for these new variables. As a result, we were unable to include them in the regression analysis.

32 As robustness check, we explored other potential environmental cost factors such as the poverty rate, population density, jobs per capita, the percentage of the population that is foreign-born, the percentage of the population that is black, and the percentage of the population that is Hispanic. Including these variables does not fundamentally affect other results; however, none of these variables is statistically significant. In the case of the poverty rate, it is not statistically significant, likely because it is highly correlated with both personal income and the unemployment rate. 
smoothing out the actuarial value of their assets over three to five years. In addition, because pension and OPEB ARCs are currently small relative to other spending categories, the decision whether to remove the cyclical influence on ARCs or not is unlikely to fundamentally affect our assessment of state and local fiscal sustainability.

\section{Estimating a Trend Gap}

We estimate each state's trend revenue and expenditure in each year, using the regression coefficients (including state and year fixed effects) and the actual value of each variable, after adjusting the unemployment rate and personal income to remove the short-term influence of business cycles.

Following the high-employment budget approach, we replace the value of the unemployment rate with an estimated natural rate of unemployment (NAIRU) for each state in each year. While the Congressional Budget Office (CBO) estimates the national NAIRU, there is no official estimate of the state-level NAIRU. In order to estimate the state-level NAIRU, we assume that the ratio of the NAIRU to the actual unemployment rate is uniformly distributed across the country. Therefore, we can multiply each state's actual unemployment rate in each year by the ratio of the CBO's estimate of the national NAIRU to the national unemployment rate in the same year to obtain an estimate of the state-level NAIRU.

We replace the value of personal income with the so-called "trend income" of each state in each year. We first model each state's personal income as a function of national GDP, the state unemployment rate, educational attainment, age composition, and state fixed effects (Table 4). We then estimate each state's trend income based on this regression model, after replacing the value of the unemployment rate with the estimated state-level NAIRU, and national GDP with the CBO's estimate of national potential GDP.

Because of the adjustments to the unemployment rate and GDP, the estimated nationwide per capita trend income shows less sensitivity to business cycles than actual income does (Figure 1). Trend income is mostly lower than actual income from the mid-1980s until the Great Recession, largely because the CBO's estimate of potential GDP was below actual GDP 
during most of this period. Trend income declined slightly in 2010 because of the recent increase in the CBO's estimate of the NAIRU and the stagnancy of the CBO's estimate of potential GDP. ${ }^{33}$ Nonetheless, it was still higher than actual income.

We estimate each state's trend revenue and expenditure based on the state-level NAIRU and trend income. As Figure 2 shows, nationwide per capita trend revenue ran under actual revenue from the 1990s until the Great Recession, because trend income was mostly lower than actual income during this period. In addition, trend revenue dropped in 2010, because trend income declined in that year and tax revenues were rather income elastic.

Similarly, nationwide per capita trend expenditure mostly remained below actual expenditure when neither takes into account pension or OPEB ARCs (Figure 3). This is largely because estimated trend income and the CBO's estimate of the NAIRU were lower than actual income and the actual unemployment rate during most of the sample period.

As expected, the trend gap is less responsive to recessions than the actual gap (Figure 4). The nationwide per capita actual gap increased faster than the national trend gap during recession periods, showing that our approach indeed mitigates cyclical influences. However, the trend gap still appears somewhat cyclical during the 2000s. We believe the main explanation for this is that the CBO's estimate of the NAIRU was at its historical low before the Great Recession and then, together with the CBO's estimate of potential GDP, was affected considerably by the Great Recession. ${ }^{34}$ It is also possible that year fixed effects capture not only the national health care inflation rates, but also cyclical influences not accounted for by the unemployment rate and personal income. ${ }^{35}$

\footnotetext{
33 The CBO's estimate of the national NAIRU is slightly U-shaped during our sample period, as it declined from 6.2 percent in 1980 to a historically low 5 percent between 2000 and 2007, and then jumped to 5.4 percent in 2010.

${ }^{34}$ While it is possible that this measure of trend gap may still contain some indirect effects of business cycles, we argue that the recent increase in trend gap should still be considered largely "structural," because it is ultimately traceable back to the change in the CBO's estimate of the NAIRU and potential GDP.

${ }^{35}$ We later use the Hodrick-Prescott filter as an alternative way of removing short-term cyclical influences, including those potentially captured by year fixed effects.
} 
Overall, the nationwide per capita trend gap was on an increasing path during the past three decades, even without considering pension or OPEB costs (Figure 5). The trend gap is even larger after adding pension and OPEB ARCs.

The overall state and local government sector has faced a large trend gap in the last decade. The nationwide per capita trend gap without pension or OPEB ARCs was already above zero during most of the 2000s. The full trend gap, including pension and OPEB ARCs, reached over $\$ 1,000$ per capita in $2010 .{ }^{36}$ This means that excluding short-term cyclical influences, the revenue-raising capacity of state and local governments fell short of the amount needed to meet public service demand and fulfill long-term obligations by over $\$ 1,000$ per capita in 2010. Furthermore, because we underestimate pension and OPEB ARCs, the true trend gap may be larger than our model indicates.

These results differ from the GAO's findings (2008, 2011, and 2012). The GAO studies show no clear trend in their measure of operating balance as a percentage of GDP during the last three decades. To facilitate a proper comparison with the GAO studies, we also divide the trend gap by GDP. Figure 6 shows that the nationwide trend gap as a percentage of GDP increased over time. The full trend gap of state and local governments reached more than 2 percent of GDP in 2010.

To test the sensitivity of the trend gap measure to the high-employment budget approach, we use a filter technique as an alternative way of removing the short-term influence of business cycles on revenues and expenditures. We first calculate expected revenues and expenditures based on our regression coefficients (including state and year fixed effects) and the actual value of each variable, without adjusting the unemployment rate or personal income. Then, we use the Hodrick-Prescott (HP) filter to separate the trend component from the cyclical component of total expected revenues and expenditures. ${ }^{37}$ The difference between the trend component of total expected expenditures and the trend component of total expected revenues

\footnotetext{
${ }^{36}$ Forty-five states had a positive trend gap including pension and OPEB ARCs in 2010.

${ }^{37}$ According to the Ravn Uhlig rule, the smoothing parameter of the HP filter is set at 6.25 for annual data. Because the time series of pension and OPEB ARCs is too short for the filter, we add pension and OPEB ARCs directly to the nonpension, nonOPEB trend gap to obtain the measure of the full trend gap.
} 
is an alternative measure of the trend gap. As Figure 7 indicates, the nationwide per capita trend gap calculated from the HP filter shows a similar growth pattern to the one calculated with the high-employment budget approach. The full trend gap in 2010 calculated from the HP filter is even larger than the one calculated with the high-employment budget approach. Thus, our results are robust to common methods of removing cyclicality from the estimates.

\section{Sources of the Growth in the Trend Gap}

SSIM is a major force behind the growth in the trend gap. We cannot pinpoint what portion of the trend gap is attributable to each expenditure function, because it is impossible to know, based on available data, what portion of trend revenue should be allocated to each expenditure function. Instead, we can examine indirectly which expenditure function is most responsible for the increase in the trend gap. All the nonpension and nonOPEB subcategories of nationwide per capita trend expenditures, except transportation and other expenditures, have grown faster than trend revenue in the last three decades (Figure 8, all estimated using the highemployment budget approach). In particular, trend SSIM expenditures have grown the fastest, with an average annual growth rate of 3.0 percent, which is 1.3 percentage points above the average annual growth rate of trend revenues. Its rapid growth rate and large relative size suggest that SSIM has played the most important role in raising the trend gap during the last three decades.

Pension and OPEB ARCs have also been growing fast and are increasingly important in driving up the trend gap. Because of data limitations, we can calculate the annual growth rate of pension and OPEB ARCs only for recent years. Pension ARCs grew 8.6 percent annually from 2001 to 2010. OPEB ARCs grew 6.5 percent annually from 2008 to 2010. Because pension and OPEB ARCs are still relatively small compared with other expenditure categories, they are not currently a major driver of growth in the trend gap. However, their role will become increasingly important if they continue to grow at current rates relative to the growth rate of revenues. 


\section{Regional Disparities}

While the growth pattern of the trend gap is similar across the country, there are noticeable regional differences in the size of the trend gap (Figure 9). For example, the Pacific division's full trend gap in 2010 is statistically significantly higher than the full trend gap of every other census division, except for New England. ${ }^{38}$

There are also great disparities in the trend gap across states, and these disparities have grown over time. We measure disparities in the trend gap by calculating the range between the $80^{\text {th }}$ percentile and the $20^{\text {th }}$ percentile or between the $90^{\text {th }}$ percentile and the $10^{\text {th }}$ percentile in each year. Even without pension or OPEB ARCs, the two range measures are over $\$ 700$ and $\$ 1,000$ per capita for 2010 , respectively (Figure 10). These numbers rise to over $\$ 800$ and $\$ 1,500$ per capita in 2010 if we include pension and OPEB ARCs. In addition, both range measures have increased over the last three decades, which indicates growing disparities among states. ${ }^{39}$

We explore what underlying factors may contribute to growing disparities in the trend gap. To do so, we calculate the two range measures for factors that determine the trend gap (Table 5). Both range measures for 2010 are larger than those for 1980 or 2001 for personal income, federal revenue transfers, the unemployment rate, the percentage of population of age 25 or older with at least a bachelor's degree, and pension ARCs. ${ }^{40}$ This suggests that disparities in these underlying factors have grown over time, contributing to the increasing disparities in the trend gap across states.

We investigate observable socioeconomic characteristics in states with a large trend gap. We calculate correlations between the full trend gap (including pension and OPEB ARCs) and common socioeconomic characteristics across states over the 2008-to-2010 period (Table 6). We

\footnotetext{
${ }^{38}$ Because our regression model does not allow coefficients to vary by region or state, the measures of individual regions' or states' trend gap are likely imprecise.

${ }^{39}$ We calculate the standard deviation of the state trend gap in each year as another measure of disparities. Overall, this measure has also grown over time. The standard deviation of the trend gap without pension or OPEB ARCs for 2010 is much larger than the standard deviation for 1980, and the difference between the two is statistically significant.

40 Similarly, the standard deviation of these variables and OPEB ARCs for 2010 is larger than the standard deviation for 1980 (or 2001 for pension ARCs or 2008 for OPEB ARCs). The difference between the two standard deviations is statistically significant.
} 
present both the regular correlation coefficient and the Kendall's rank correlation coefficient, because the latter measure is less sensitive to outliers. Overall, large-gap states tend to have a larger population, a higher unemployment rate, and a higher share of either population of age 25 years old or older without a high school degree or population of age 25 years old or older with at least a bachelor's degree. The trend gap is also positively correlated with personal income according to the Kendall's rank correlation coefficient, but only at the 10 percent significance level.

Most of these socioeconomic characteristics contribute to the trend gap through their impact on either revenues or expenditures or both. A larger share of population of age 25 years old or older without a high school degree would lower trend revenues (Table 2). A higher unemployment rate and a larger share of population of age 25 years old or older with at least a bachelor's degree would increase trend expenditures (Table 3). ${ }^{41}$ Population size is positively correlated with the trend gap (Table 6), because it turns out to be positively and significantly correlated with the unemployment rate and the share of population of age 25 years old or older without a high school degree, which would increase trend expenditures and lower trend revenues, respectively.

\section{Conclusion}

This paper develops and estimates a new measure of state and local fiscal sustainability called the trend gap, which is based on socioeconomic and other fundamental factors and removes the short-term influence of the business cycle. The trend gap provides a more accurate picture than existing measures of the fiscal sustainability of U.S. state and local governments. .

Differing from GAO studies, this paper finds that the nationwide per capita trend gap has grown over the past three decades. As a result, by the late 2000s the state and local government sector faced a large shortfall in fiscal sustainability. Social insurance and income maintenance programs have played a major role in the growth of the trend gap. While pension and OPEB ARCs are still relatively small compared with other expenditure categories, they are

\footnotetext{
${ }^{41}$ In each year, a state with a higher unemployment rate is assumed to have a higher NAIRU, because we assume that the ratio of the NAIRU to the unemployment rate is uniformly distributed across the country.
} 
becoming increasingly important in driving up the trend gap. In addition, we find that there are large and growing disparities across states in fiscal sustainability as measured by the trend gap.

This paper does not forecast future trend gaps, an area that deserves more research, given the great uncertainty surrounding ongoing pension and OPEB reform, efforts at federal deficit reduction, and the impact of implementing the Affordable Care Act. Nonetheless, this expost analysis is important and necessary, because future projections should be based on an accurate measure of the current prospects for state and local government finances. When previous studies have projected future fiscal gaps, they have simply applied estimated longterm growth rates to actual revenues and expenditures of a base year. In so doing, they have implicitly assumed that the influence of business cycles and idiosyncratic factors in the base year will persist indefinitely. If the base year is a recession (or boom) year, such projections will likely overestimate (or underestimate) future gaps. Therefore, we recommend that future research employ the trend gap methodology, which would improve upon the projections made using previous approaches.

Because state and local governments face a number of downside risks, their fiscal sustainability may become more concerning in the medium or even near term. First, the Congressional Budget Office expects the national economy to grow only moderately in the next 10 years. It forecasts the annual growth rate of potential GDP to be below 2 percent before 2015 and between 2 and 2.5 percent from 2015 to 2023 (CBO 2013). This is lower than its nearly 3 percent estimate of the average annual growth rate of potential GDP for the 1980-to-2008 period. Second, the CBO expects the NAIRU to remain elevated for a considerably long period. It estimates that the NAIRU will remain at 5.5 percent through the end of this decade and then slowly decline to 5.3 percent in 2023 (CBO 2013). Third, federal grants to state and local governments will almost certainly be cut in the near future. The cuts in federal grants are potentially large and may cause considerable fiscal stress to state and local governments. ${ }^{42}$ Moreover, a larger portion of state and local pension and OPEB liabilities may turn out to be

42 Chernick, Langley, and Reschovsky (2012) estimate that inflation-adjusted federal government outlays on intergovernmental grants to state and local governments would drop by 37.7 percent between 2009 and 2013 if President Obama's FY 2013 budget were adopted. 
unfunded as more data are disclosed. Because these are serious downside risks and largely outside the control of state and local governments, it is unlikely that trend gaps will decline significantly in the near future. ${ }^{43}$

${ }^{43}$ The State Budget Crisis Task Force (2012) notes that fiscal problems facing state and local governments would not self-correct and are likely to get worse if they are not addressed soon. 


\section{References}

Afonso, António and Christophe Rault. 2010. "What Do We really Know about Fiscal Sustainability in the EU? A Panel Data Diagnostic." Review of World Economics 145:731-755.

Bernanke, Ben S. 2010. "Achieving Fiscal Sustainability." Remarks made to the National Commission on Fiscal Responsibility and Reform in Washington, DC on April 27, 2010.

Bradford, David F., R. A. Malt, and Wallace E. Oates. 1969. “The Rising Cost of Local Public Services: Some Evidence and Reflections." National Tax Journal 22(2):185-202.

Bruce, Donald, William F. Fox, and M.H. Tuttle. 2006. “Tax Base Elasticities: A Multi-State Analysis of Long-Run and Short-Run Dynamics." Southern Economic Journal 73(2):315-341.

Chapman, Jeffrey I. 2008. "State and Local Fiscal Sustainability: The Challenges." Public Administration Review 68(6): S115-S131.

Chernick, Howard, Adam Langley, and Andrew Reschovsky. 2012. "Predicting the Impact of the U.S. Housing Crisis and "Great Recession" on Central City Revenues." Publius: The Journal of Federalism 42(3):467-493.

Congressional Budget Office. 2013. The Budget and Economic Outlook: Fiscal Years 2013 to 2023. Washington, DC: Congressional Budget Office.

Cooper, Michael and Mary Williams Walsh. 2010. "Crushing Debt Facing State Governments Stokes Fear in Financial Analysts." The Boston Globe, December 5.

Croce, Enzo and V. Hugo Juan-Ramón. 2003. “Assessing Fiscal Sustainability: A Cross-Country Comparison." IMF Working Paper WP/03/145. Washington, DC: International Monetary Fund.

Dye, Richard F. and Nancy Hudspeth. 2010. "The Fiscal Futures Project: Progress Report and Initial Results." Chicago, IL: University of Illinois Institute of Government and Public Affairs.

Fitch Ratings. 2013. “California OPEB Decision Could Be Credit Negative." Fitch Ratings Wire News: New York, New York, October 2.

Governmental Accounting Standards Board. 2011. Economic Condition Reporting: Financial Projections: Preliminary Views No. 13-3.

Governmental Accounting Standards Board. 2012. GASB Improves Pension Accounting and Financial Reporting Standards. 
Gramlich, John. 2011. “Municipal Bankruptcy Explained: What it Means to File for Chapter 9." Stateline by the Pew Center on the States, November 22.

Ladd, Helen F. and John Yinger. 1989. America's Ailing Cities. Baltimore, MD: The Johns Hopkins University Press.

Mahdavi, Saeid and Joakim Westerlund. 2011. "Fiscal Stringency and Fiscal Sustainability: Panel Evidence from the American State and Local Governments." Journal of Policy Modeling 33:953-969.

National Association of State Budget Officers. 2012. State Expenditure Report: Examining Fiscal 2010-2012 State Spending.

National Conference of State Legislatures. 2010. NCSL Fiscal Brief: State Balanced Budget Provisions. Washington, DC: National Conference of State Legislatures.

Novy-Marx, Robert and Joshua Rauh. 2009. "The Liabilities and Risks of State-Sponsored Pension Plans." Journal of Economics Perspectives 23(4):191-210.

Novy-Marx, Robert and Joshua Rauh. 2012. “The Revenue Demands of Public Employee Pension Promises." NBER working paper No. 18489. NBER: Cambridge, MA.

Pew Center on the States. 2010. The Trillion Dollar Gap: Underfunded State Retirement Systems and the Roads to Reform. Washington, DC: The Pew Charitable Trusts.

Pew Center on the States. 2011. The Widening Gap: The Great Recession's Impact on State Pension and Retiree Health Care Costs. Washington, DC: The Pew Charitable Trusts.

Pew Center on the States. 2013. A Widening Gap in Cities: Shortfalls in Funding for Pensions and Retiree Health Care. Washington, DC: The Pew Charitable Trusts.

Poterba, James M. 1996. "Demographic Structure and the Political Economy of Public Education." NBER working paper No. 5677. NBER: Cambridge, MA.

Reid, Tim. 2012. "San Bernadino, California, Files for Bankruptcy with Over $\$ 1$ Billion in Debts." Reuters, August 2.

Snell, Ron. 2012. State Pension Reform, 2009-2011. Washington, DC: National Conference of State Legislatures.

State Budget Crisis Task Force. 2012. Report of the State Budget Crisis Task Force. 
Ulbrich, Holley Hewitt. 1997. "The Fiscal Sustainability of the South Carolina Revenue and Expenditure System 1997-2010." Clemson, SC: Strom Thurmond Institute of Government and Public Affairs.

U.S. Government Accountability Office. 2008. State and Local Governments Fiscal Outlook Will Emerge during the Next 10 Years. Washington, DC: U.S. Government Accountability Office.

U.S. Government Accountability Office. 2011. State and Local Governments Fiscal Outlook April 2011 Update. Washington, DC: U.S. Government Accountability Office.

U.S. Government Accountability Office. 2012. State and Local Governments Fiscal Outlook April 2012 Update. Washington, DC: U.S. Government Accountability Office.

Ward, Robert B. and Lucy Dadayan. 2009. "State and Local Finance: Increasing Focus on Fiscal Sustainability." Publius: The Journal of Federalism 39(3):455-475.

Young, J.E. 2009. State Fiscal Sustainability: A New Theoretical Approach and Case Study of the State of Arizona. Doctoral Dissertation. Phoenix, AZ: Arizona State University. 
Table 1. Summary Statistics for Revenue and Expenditure Categories (population-weighted per capita, in 2010 dollars, 1980-2010 unless otherwise indicated)

\begin{tabular}{lcccc}
\hline & Mean & $\begin{array}{c}\text { Standard } \\
\text { deviation }\end{array}$ & Minimum & Maximum \\
\hline Revenues & 6,955 & 1,870 & 3,488 & 32,856 \\
Tax revenue & 3,569 & 1,014 & 1,622 & 14,721 \\
Other own-source revenue & 2,137 & 697 & 834 & 16,566 \\
Federal revenue transfers & 1,249 & 480 & 544 & 6,490 \\
Nonpension and NonOPEB Expenditures & 6,981 & 1,942 & 3,359 & 22,508 \\
Education & 2,165 & 519 & 1,066 & 4,791 \\
Social services and income maintenance & 1,538 & 580 & 492 & 5,629 \\
Transportation & 501 & 152 & 99 & 2,804 \\
Public safety & 510 & 191 & 134 & 2,134 \\
Environment and housing & 501 & 175 & 190 & 3,094 \\
Government administration & 327 & 113 & 130 & 1,400 \\
Interest on general debt & 303 & 134 & 74 & 3,489 \\
Other expenditures & 1,136 & 521 & 367 & 5,751 \\
Pension and OPEB & & & & \\
Pension ARCs (2001-2010) & 181 & 93 & 2 & 686 \\
Actual pension contributions (2001-2010) & 155 & 84 & 2 & 929 \\
OPEB ARCs (2008-2010) & 158 & 146 & 0 & 1,558 \\
Actual OPEB contributions (2008-2010) & 54 & 64 & 0 & 1,200 \\
\hline
\end{tabular}

Note: Statistics are weighted by state population and converted into 2010 dollars. Other own-source revenue includes current charges, miscellaneous revenues, utility revenue, liquor store revenue, unemployment compensation revenue, and workers' compensation revenue. Other expenditures include direct general expenditures not elsewhere classified, utility expenditures, liquor store expenditures, intergovernmental expenditures, unemployment compensation expenditures, and workers' compensation expenditures. The minimum value of per capita OPEB ARCs $(2008-2010)$ is $\$ 0.04$, and rounded to zero in the table.

Source: Data on revenues and nonpension, nonOPEB expenditures are from Census Bureau's Annual Survey of State and Local Government Finances. Pension and OPEB data are from the Pew Center on the States (2010 and 2011). 
Table 2. Regression Results for Combined State and Local Revenue Categories, 1980-2010

\begin{tabular}{|c|c|c|}
\hline & $\log ($ tax revenue) & $\begin{array}{c}\log \text { (other own-source } \\
\text { revenue) }\end{array}$ \\
\hline \multirow[t]{2}{*}{$\log ($ personal income) } & $1.234 * * *$ & $0.697 * * *$ \\
\hline & $(0.352)$ & (0.226) \\
\hline \multirow[t]{2}{*}{ Percentage of population 25 or older without a high school degree } & $-0.004 * *$ & $-0.007 * *$ \\
\hline & $(0.002)$ & $(0.003)$ \\
\hline \multirow[t]{2}{*}{ Percentage of population 25 or older with at least a bachelor's degree } & 0.002 & $0.009 * * *$ \\
\hline & $(0.003)$ & $(0.003)$ \\
\hline \multirow[t]{2}{*}{ Constant } & -4.707 & 0.539 \\
\hline & $(3.482)$ & $(2.223)$ \\
\hline State fixed effects & Yes & Yes \\
\hline Year fixed effects & Yes & Yes \\
\hline $\mathrm{N}$ & 1,479 & 1,479 \\
\hline Adjusted R-squared & 0.936 & 0.933 \\
\hline
\end{tabular}

Note: We use unweighted regressions. ${ }^{* *} p<0.01, * * p<0.05, * p<0.1$. Standard errors are clustered by state and presented in parentheses. All revenue categories and personal income are in real, per capita terms.

Source: Authors' calculations. 
Table 3. Regression Results for Combined State and Local Expenditure Categories, 1980-2010

\begin{tabular}{|c|c|c|c|c|c|c|c|}
\hline & $\begin{array}{l}\text { log(education } \\
\text { expenditures) }\end{array}$ & $\begin{array}{l}\text { log(social services and } \\
\text { income maintenance } \\
\text { expenditures) }\end{array}$ & $\begin{array}{l}\log \text { (public safety } \\
\text { expenditures) }\end{array}$ & $\begin{array}{l}\log (\text { transportation } \\
\text { expenditures) }\end{array}$ & $\begin{array}{l}\text { log(environment } \\
\text { and housing } \\
\text { expenditures) }\end{array}$ & $\begin{array}{l}\text { log(government } \\
\text { administration } \\
\text { expenditures) }\end{array}$ & $\begin{array}{l}\log \text { (other } \\
\text { expenditures) }\end{array}$ \\
\hline $\log ($ personal income) & $\begin{array}{l}0.760^{* * *} \\
(0.170)\end{array}$ & $\begin{array}{l}0.435^{* * *} \\
(0.159)\end{array}$ & $\begin{array}{l}0.536^{*} \\
(0.319)\end{array}$ & $\begin{array}{l}0.627^{* * *} \\
(0.154)\end{array}$ & $\begin{array}{l}1.150^{* * *} \\
(0.258)\end{array}$ & $\begin{array}{l}0.779^{* * *} \\
(0.266)\end{array}$ & $\begin{array}{l}0.667^{* * *} \\
(0.166)\end{array}$ \\
\hline $\log ($ federal revenue transfers) & $\begin{array}{r}0.049 \\
(0.044)\end{array}$ & $\begin{array}{l}0.454^{* * *} \\
(0.076)\end{array}$ & $\begin{array}{l}0.206 * * * \\
(0.064)\end{array}$ & $\begin{array}{l}0.209 * * \\
(0.100)\end{array}$ & $\begin{array}{l}0.226 * * * \\
(0.080)\end{array}$ & $\begin{array}{l}0.125 * * \\
(0.059)\end{array}$ & $\begin{array}{l}0.306^{* * *} \\
(0.075)\end{array}$ \\
\hline $\begin{array}{l}\text { Percentage of population } 25 \text { or older without a high school } \\
\text { degree }\end{array}$ & $\begin{array}{l}-0.008^{* * *} \\
(0.002)\end{array}$ & $\begin{array}{r}-0.002 \\
(0.003)\end{array}$ & $\begin{array}{l}-0.007^{* * *} \\
(0.002)\end{array}$ & $\begin{array}{r}-0.002 \\
(0.003)\end{array}$ & $\begin{array}{r}-0.001 \\
(0.003)\end{array}$ & $\begin{array}{l}-0.010^{* * *} \\
(0.003)\end{array}$ & $\begin{array}{r}0.001 \\
(0.003)\end{array}$ \\
\hline $\begin{array}{l}\text { Percentage of population } 25 \text { or older with at least a bachelor's } \\
\text { degree }\end{array}$ & $\begin{array}{l}0.004 * \\
(0.002)\end{array}$ & $\begin{array}{r}-0.003 \\
(0.002)\end{array}$ & $\begin{array}{l}-0.006 * \\
(0.003)\end{array}$ & $\begin{array}{l}0.006 * * \\
(0.003)\end{array}$ & $\begin{array}{r}0.003 \\
(0.003)\end{array}$ & $\begin{array}{l}-0.004 * \\
(0.002)\end{array}$ & $\begin{array}{r}0.005 * \\
(0.003)\end{array}$ \\
\hline State unemployment rate & $\begin{array}{r}0.002 \\
(0.004)\end{array}$ & $\begin{array}{l}0.014^{* * *} \\
(0.005)\end{array}$ & $\begin{array}{r}0.006 \\
(0.005)\end{array}$ & $\begin{array}{r}0.003 \\
(0.005)\end{array}$ & $\begin{array}{l}0.012 * * \\
(0.006)\end{array}$ & $\begin{array}{r}0.004 \\
(0.007)\end{array}$ & $\begin{array}{l}0.038^{* * *} \\
(0.007)\end{array}$ \\
\hline Percentage of population 65 or older & $\begin{array}{r}-0.004 \\
(0.010)\end{array}$ & $\begin{array}{r}0.017 \\
(0.016)\end{array}$ & $\begin{array}{l}-0.036 * * * \\
(0.010)\end{array}$ & & & & \\
\hline Percentage of population younger than 18 & $\begin{array}{l}0.023^{* * *} \\
(0.007)\end{array}$ & $\begin{array}{l}-0.017 * \\
(0.010)\end{array}$ & $\begin{array}{l}-0.021 * * \\
(0.009)\end{array}$ & & & & \\
\hline Constant & $\begin{array}{r}-1.010 \\
(1.770)\end{array}$ & $\begin{array}{r}-0.359 \\
(1.938)\end{array}$ & $\begin{array}{r}-0.154 \\
(3.205)\end{array}$ & $\begin{array}{l}-1.699 \\
(1.501)\end{array}$ & $\begin{array}{l}-7.591 * * * \\
(2.736)\end{array}$ & $\begin{array}{r}-3.214 \\
(2.692)\end{array}$ & $\begin{array}{r}-2.578 \\
(1.780)\end{array}$ \\
\hline $\begin{array}{l}\text { State fixed effects } \\
\text { Year fixed effects }\end{array}$ & $\begin{array}{l}\text { Yes } \\
\text { Yes }\end{array}$ & $\begin{array}{l}\text { Yes } \\
\text { Yes }\end{array}$ & $\begin{array}{l}\text { Yes } \\
\text { Yes }\end{array}$ & $\begin{array}{l}\text { Yes } \\
\text { Yes }\end{array}$ & $\begin{array}{l}\text { Yes } \\
\text { Yes }\end{array}$ & $\begin{array}{l}\text { Yes } \\
\text { Yes }\end{array}$ & $\begin{array}{l}\text { Yes } \\
\text { Yes }\end{array}$ \\
\hline $\mathrm{N}$ & 1,479 & 1,479 & 1,479 & 1,479 & 1,479 & 1,479 & 1,479 \\
\hline Adjusted R-squared & 0.949 & 0.953 & 0.965 & 0.857 & 0.918 & 0.940 & 0.933 \\
\hline
\end{tabular}

Note: We use unweighted regressions. ${ }^{* * *} p<0.01,{ }^{* *} p<0.05,{ }^{*} p<0.1$. Standard errors are clustered by state and presented in parentheses. All expenditure categories and personal income are in real, per capita terms.

Source: Authors' calculations. 
Table 4. Estimating Personal Income, 1980-2010

\begin{tabular}{lc}
\hline & log(personal income) \\
\hline State unemployment rate & $-0.004^{* * *}$ \\
log(GDP) & $(0.001)^{* * *}$ \\
& $0.681^{* * *}$ \\
Percentage of population 25 or older without a high school degree & $(0.048)$ \\
& $-0.002^{* * *}$ \\
Percentage of population 25 or older with at least a bachelor's degree & $(0.000)$ \\
Percentage of population 65 or older & $0.007^{* * *}$ \\
& $(0.001)$ \\
Percentage of population younger than 18 & $-0.024^{* * *}$ \\
Constant & $(0.003)$ \\
& $-0.021^{* * *}$ \\
State fixed effects & $(0.003)$ \\
Year fixed effects & $3.782^{* * *}$ \\
\hline $\mathrm{N}$ & $(0.555)$ \\
Adjusted R-squared & Yes \\
\hline
\end{tabular}

Note: We use unweighted regressions. ${ }^{* * *} p<0.01,{ }^{* *} p<0.05,{ }^{*} p<0.1$. Standard errors are clustered by year and presented in parentheses. Personal income and GDP are in real, per capita terms.

Source: Authors' calculations. 
Table 5. Disparities in Factors Determining the Trend Gap

\begin{tabular}{|c|c|c|c|c|}
\hline & \multicolumn{2}{|c|}{ 90th percentile minus 10th percentile } & \multicolumn{2}{|c|}{ 80th percentile minus 20th percentile } \\
\hline & 1980 & 2010 & 1980 & 2010 \\
\hline Personal income & $9,586.7$ & $15,943.7$ & $7,012.6$ & $8,277.1$ \\
\hline Federal revenue transfers & 509.5 & $1,461.7$ & 380.1 & 785.3 \\
\hline State unemployment rate & 3.7 & 4.8 & 2.2 & 3.3 \\
\hline Percentage of population 25 or older without a high school degree & 19.3 & 8.9 & 10.7 & 6.7 \\
\hline Percentage of population 25 or older with at least a bachelor's degree & 9.6 & 13.7 & 7.0 & 7.7 \\
\hline Percentage of population 65 or older & 4.6 & 3.4 & 3.1 & 2.1 \\
\hline \multirow[t]{3}{*}{ Percentage of population younger than 18} & 5.2 & 4.2 & 2.3 & 2.6 \\
\hline & \multicolumn{2}{|c|}{ 90th percentile minus 10 th percentile } & \multicolumn{2}{|c|}{ 80th percentile minus 20th percentile } \\
\hline & 2001 & 2010 & 2001 & 2010 \\
\hline \multirow[t]{3}{*}{ Pension ARC } & 169.9 & 275.8 & 113.4 & 183.9 \\
\hline & \multicolumn{2}{|c|}{ 90th percentile minus 10 th percentile } & \multicolumn{2}{|c|}{ 80th percentile minus 20th percentile } \\
\hline & 2008 & 2010 & 2008 & 2010 \\
\hline OPEB ARC & 479.0 & 541.1 & 230.2 & 196.4 \\
\hline
\end{tabular}

Source: Authors' calculations. 
Table 6. Correlation between the Trend Gap and State Socioeconomic Characteristics

\begin{tabular}{lcc} 
& Trend gap with pension and OPEB ARCs (2008-2010) \\
\cline { 2 - 3 } & Regular correlation & Kendall's rank correlation \\
\hline Population size & $0.33^{* * *}$ & $0.38^{* * *}$ \\
Personal income & 0.02 & $0.11^{*}$ \\
State unemployment rate & $0.38^{* * *}$ & $0.37^{* * *}$ \\
Percentage of population 65 or older & $0.26^{* * *}$ & -0.04 \\
Percentage of population younger than 18 & -0.09 & -0.05 \\
Percentage of population 25 or older without a high school degree & $0.27^{* * *}$ & $0.18^{* * *}$ \\
Percentage of population 25 or older with at least a bachelor's degree & $0.18^{* *}$ & $0.13^{* *}$ \\
\hline
\end{tabular}

Note: ${ }^{* *} p<0.01,{ }^{* *} p<0.05, * p<0.1$. Trend gap and personal income are in real, per capita terms.

Source: Authors' calculations. 


\section{Figure 1.Personal Income Trend vs Actual}

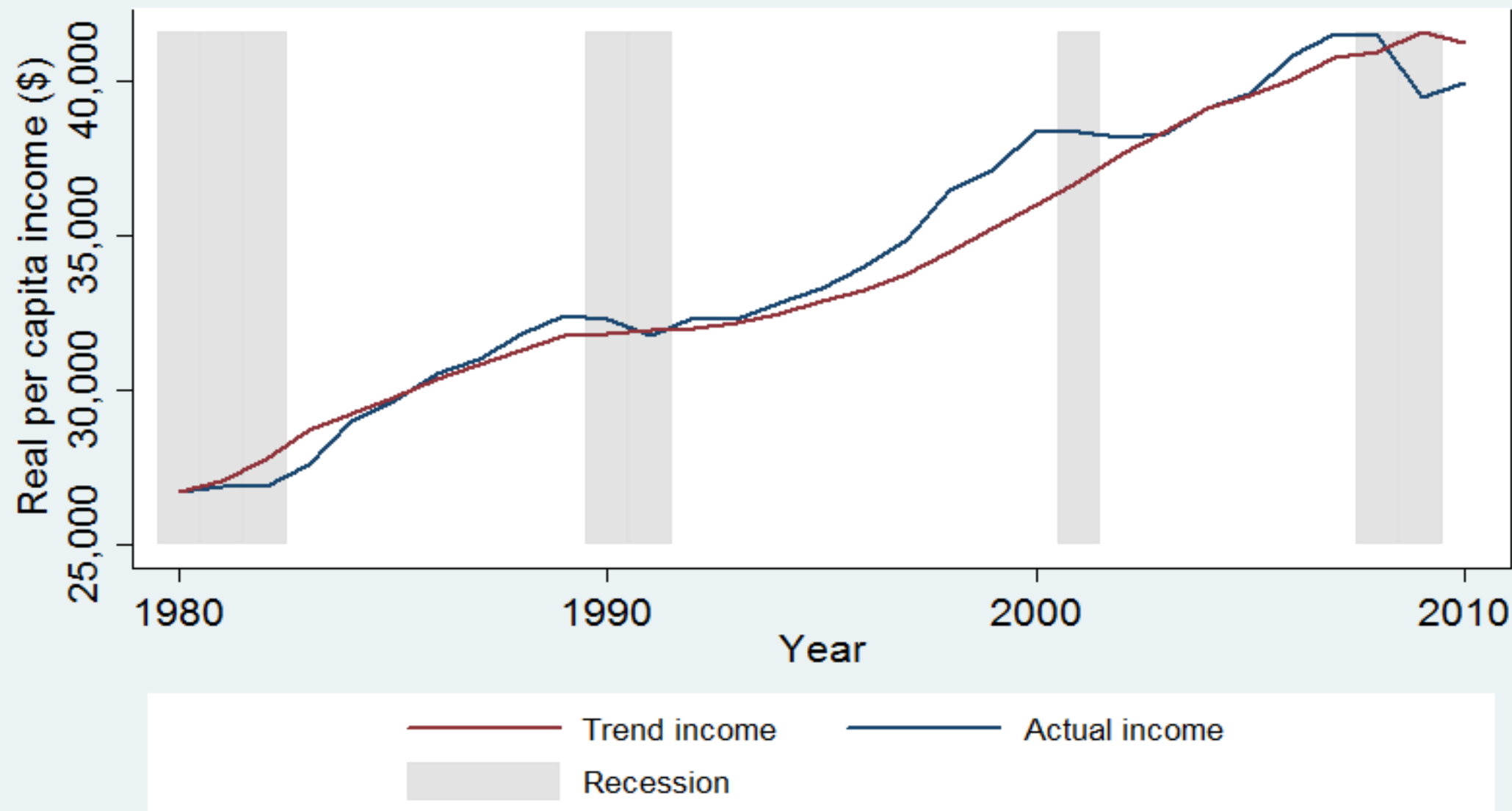

Note: Figures are U.S. population-weighted average.

Source: Authors' calculations and the U.S. Bureau of Economic Analysis. 


\section{Figure 2.State and Local Revenue Trend vs Actual}

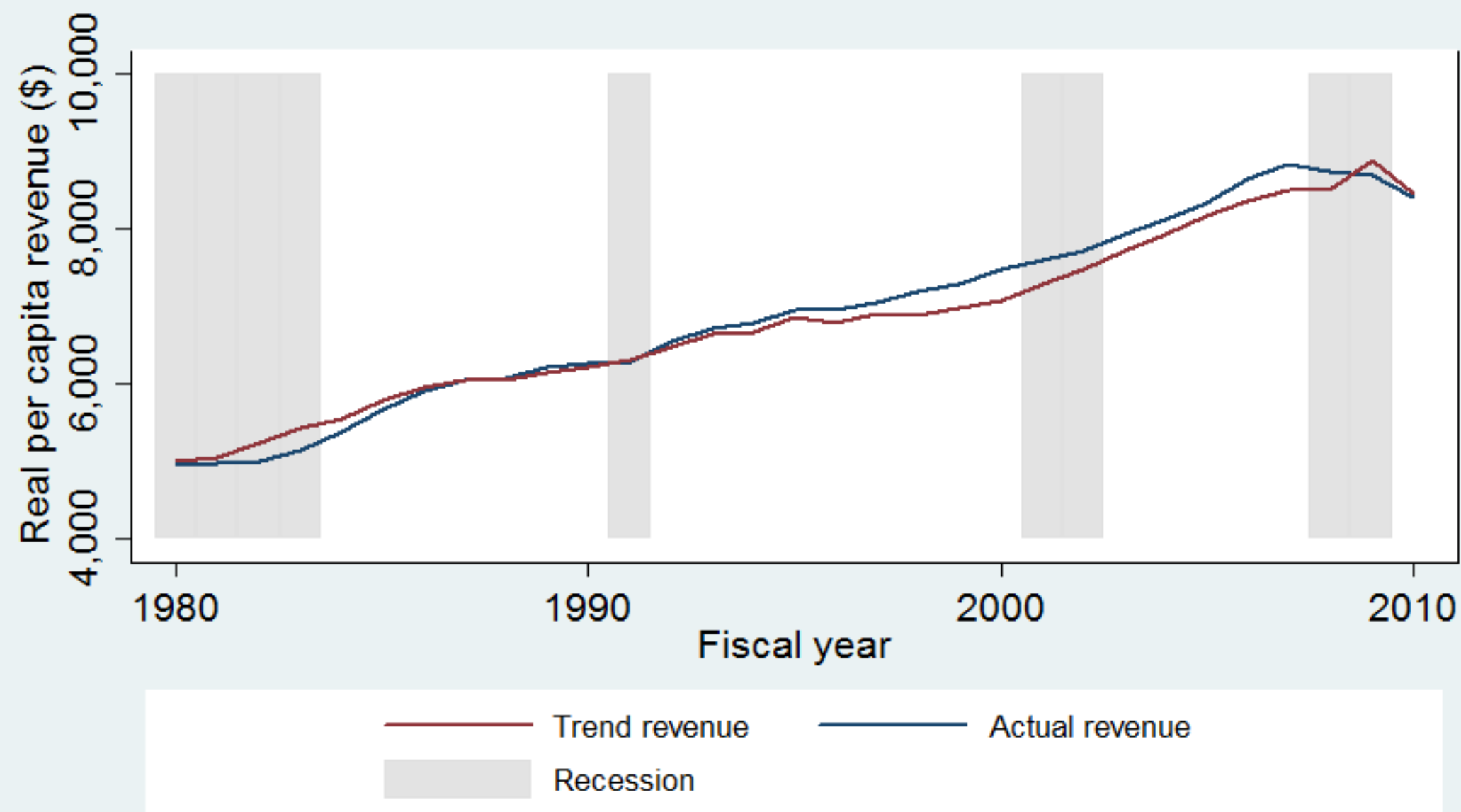

Note: Figures are U.S. population-weighted average.

Source: Authors' calculations and the U.S. Census Bureau's Annual Survey of State and Local Government Finances. 


\section{Figure 3.State and Local Expenditure Trend vs Actual}

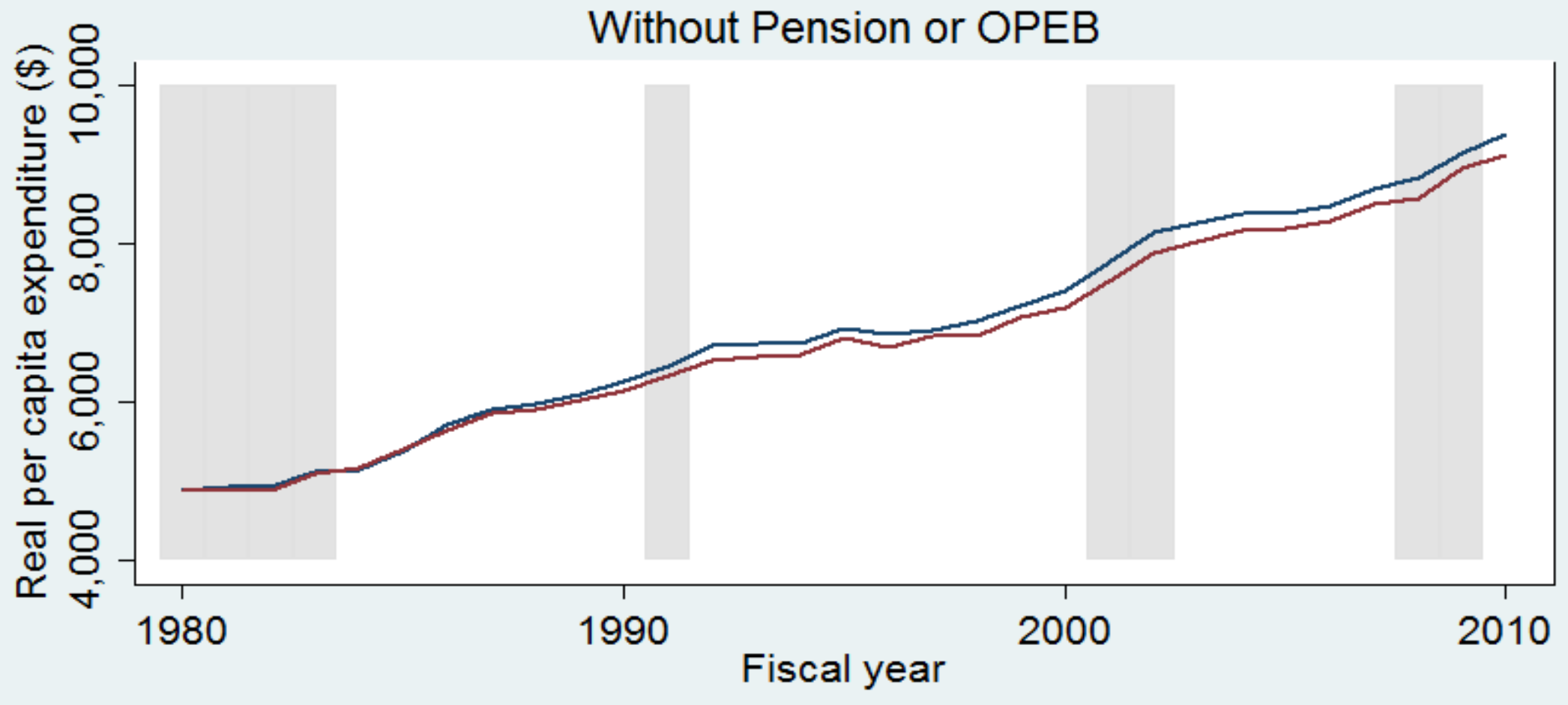

Trend expenditure

Actual expenditure

\section{Recession}

Note: Figures are U.S. population-weighted average.

Source: Authors' calculations and the U.S. Census Bureau's Annual Survey of State and Local Government Finances. 


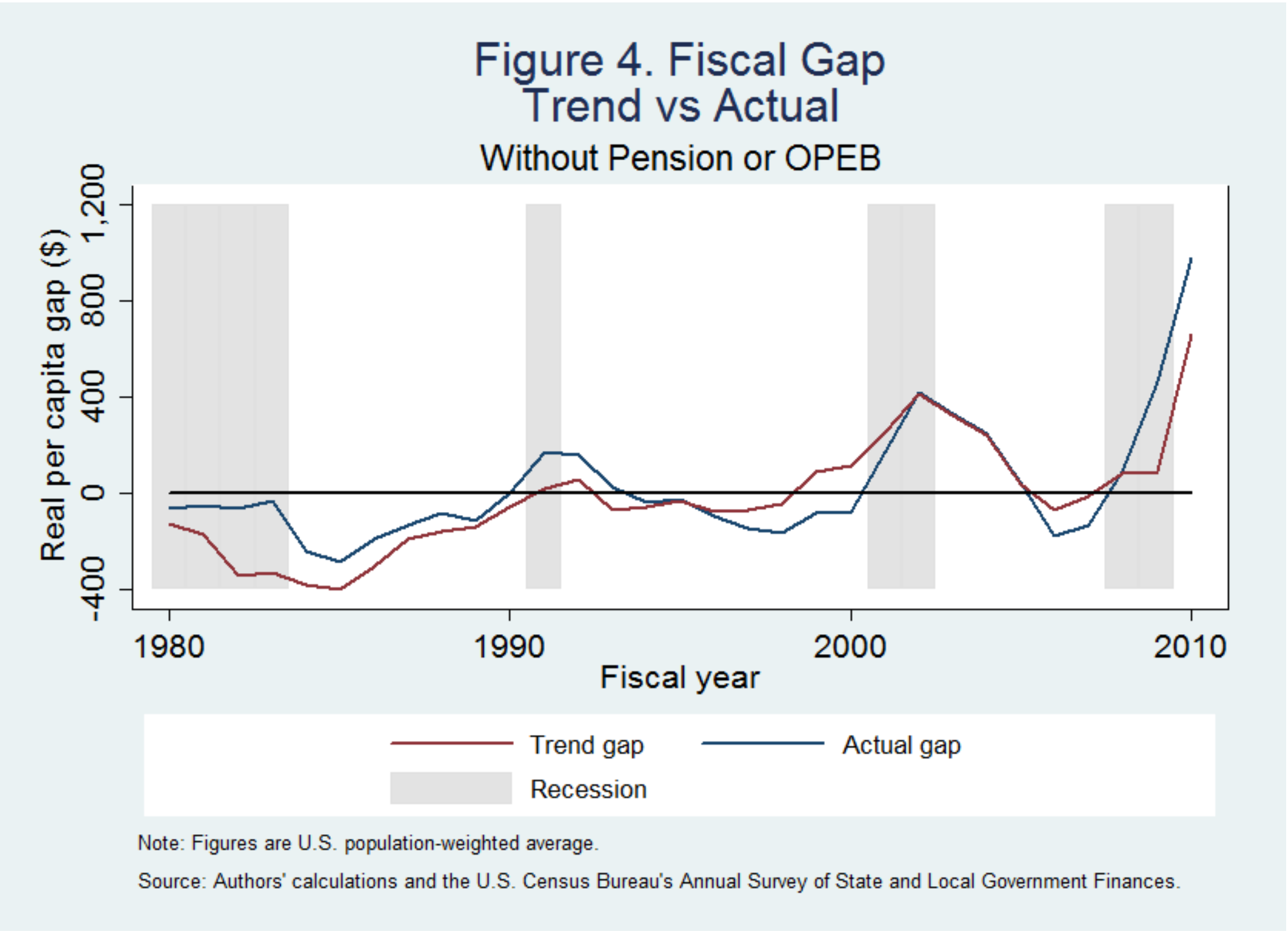




\section{Figure 5.Trend Gap}

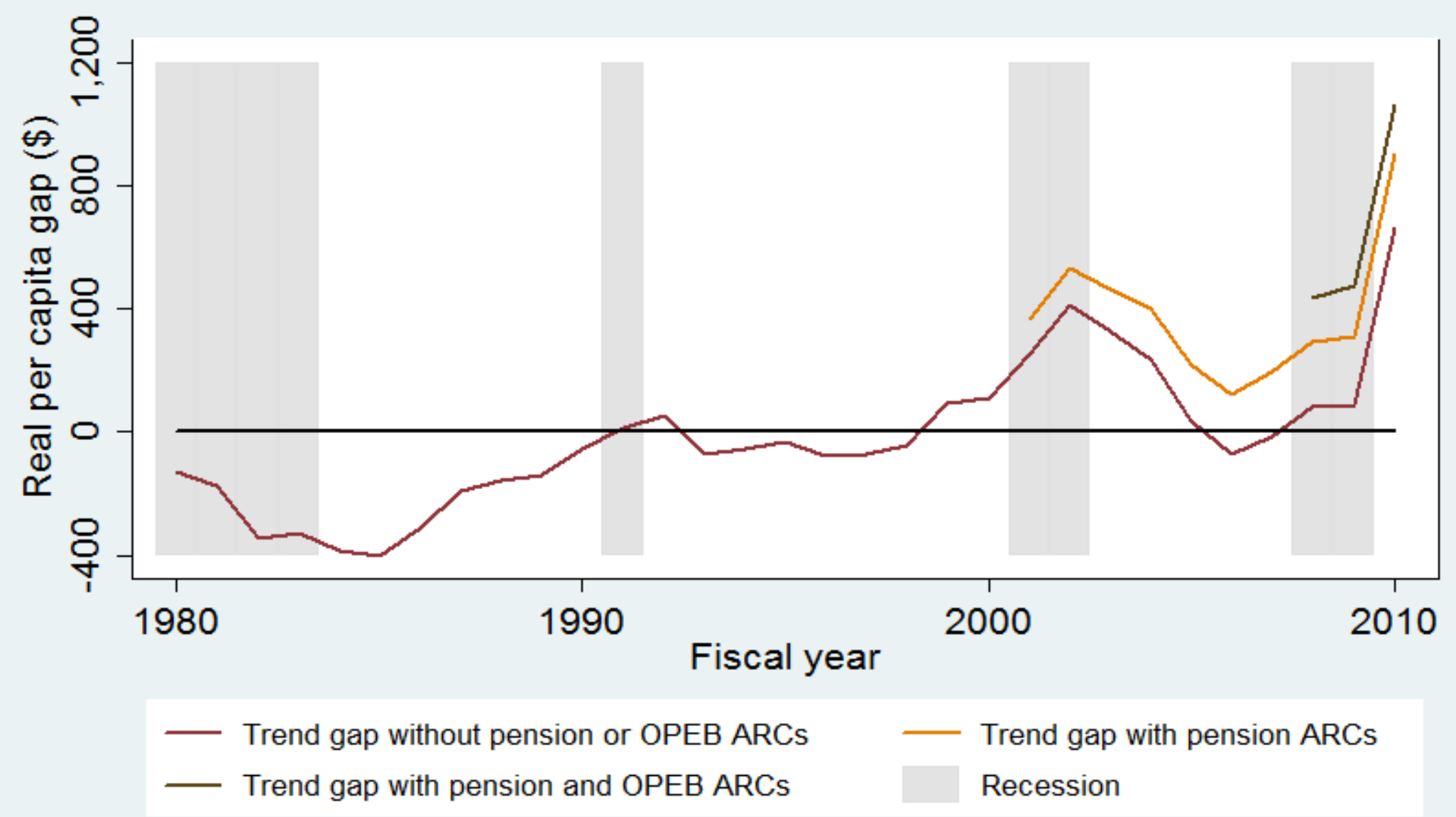

Note: Figures are U.S. population-weighted average.

Source: Authors' calculations and the Pew Center on the States (2010 and 2011). 


\section{Figure 6.Trend Gap as a Percentage of GDP}

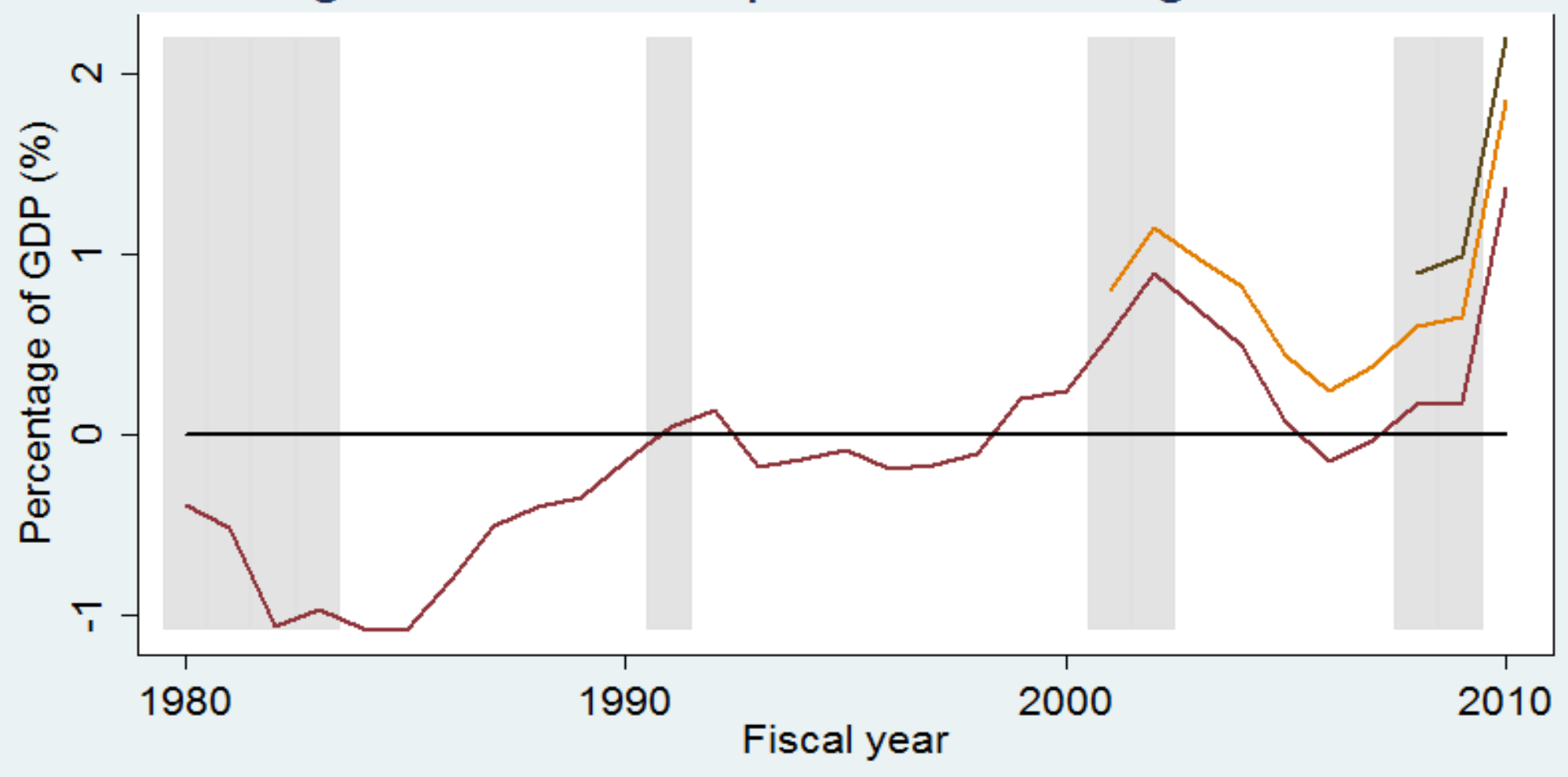

_ (Trend gap without pension or OPEB ARCs)/GDP

(Trend gap with pension ARCs)/GDP

— (Trend gap with pension and OPEB ARCs)/GDP

Recession

Note: Figures are U.S. population-weighted average.

Source: Authors' calculations, U.S. Bureau of Economic Analysis and the Pew Center on the States (2010 and 2011). 


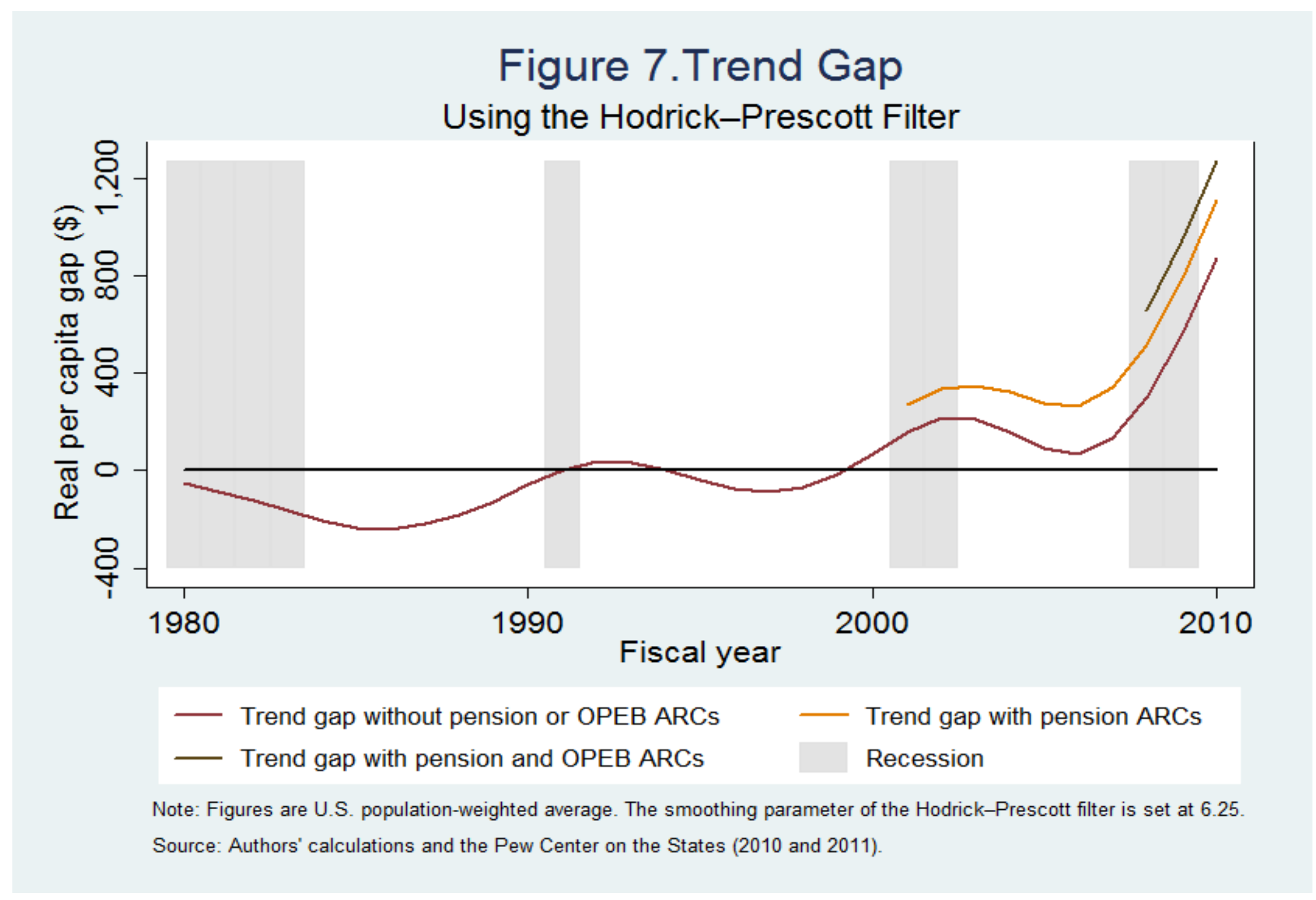


Figure 8. Average Annual Growth Rate of Trend Revenues and Trend Expenditures 1980-2010

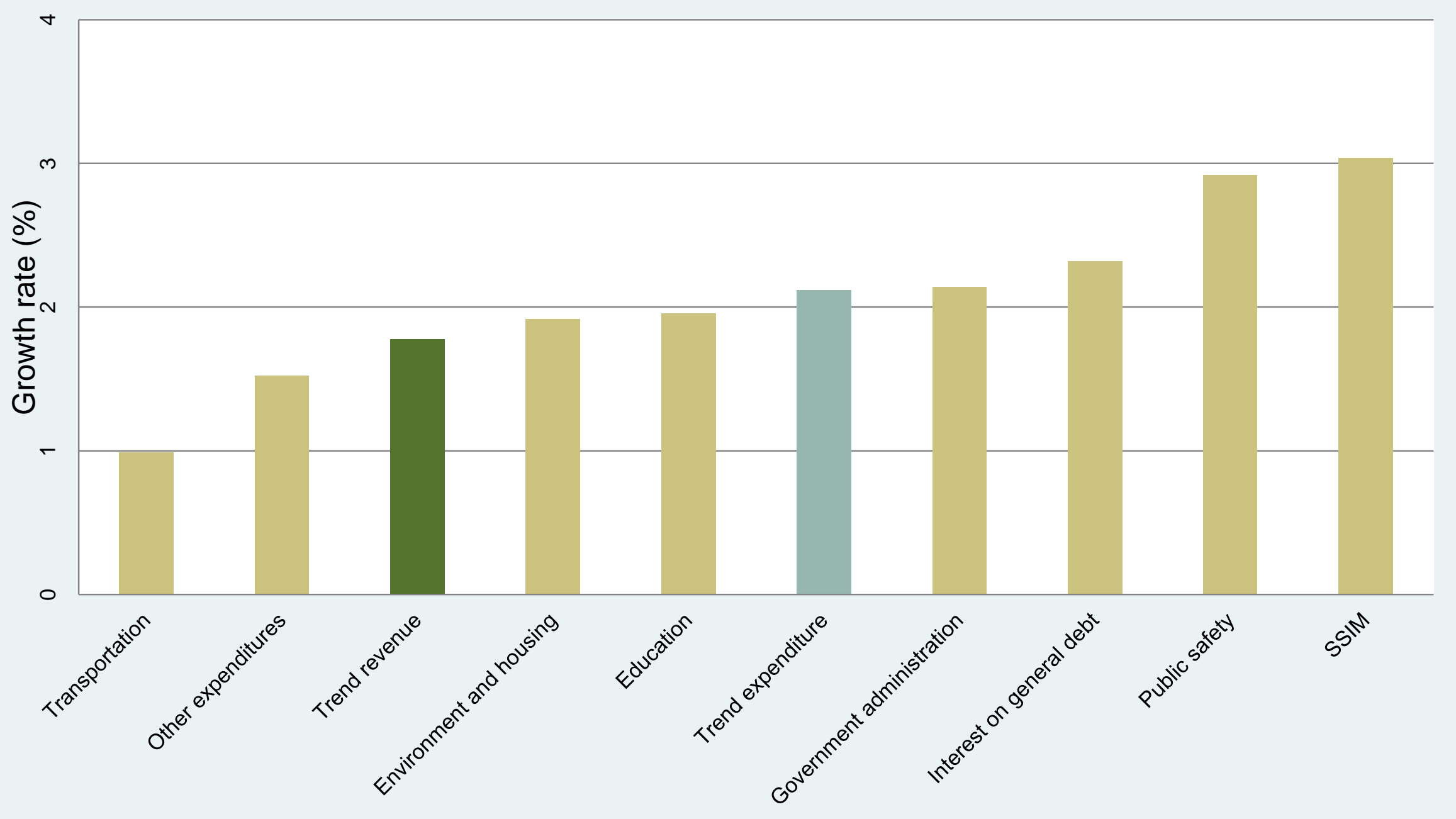

Note: Figures are U.S. population-weighted average. Trend expenditure does not include pension or OPEB ARCs.

Source: Authors' calculations. 


\section{Figure 9. 2010 Per Capita Trend Gap with Pension and OPEB ARCs}

By Census Divisions

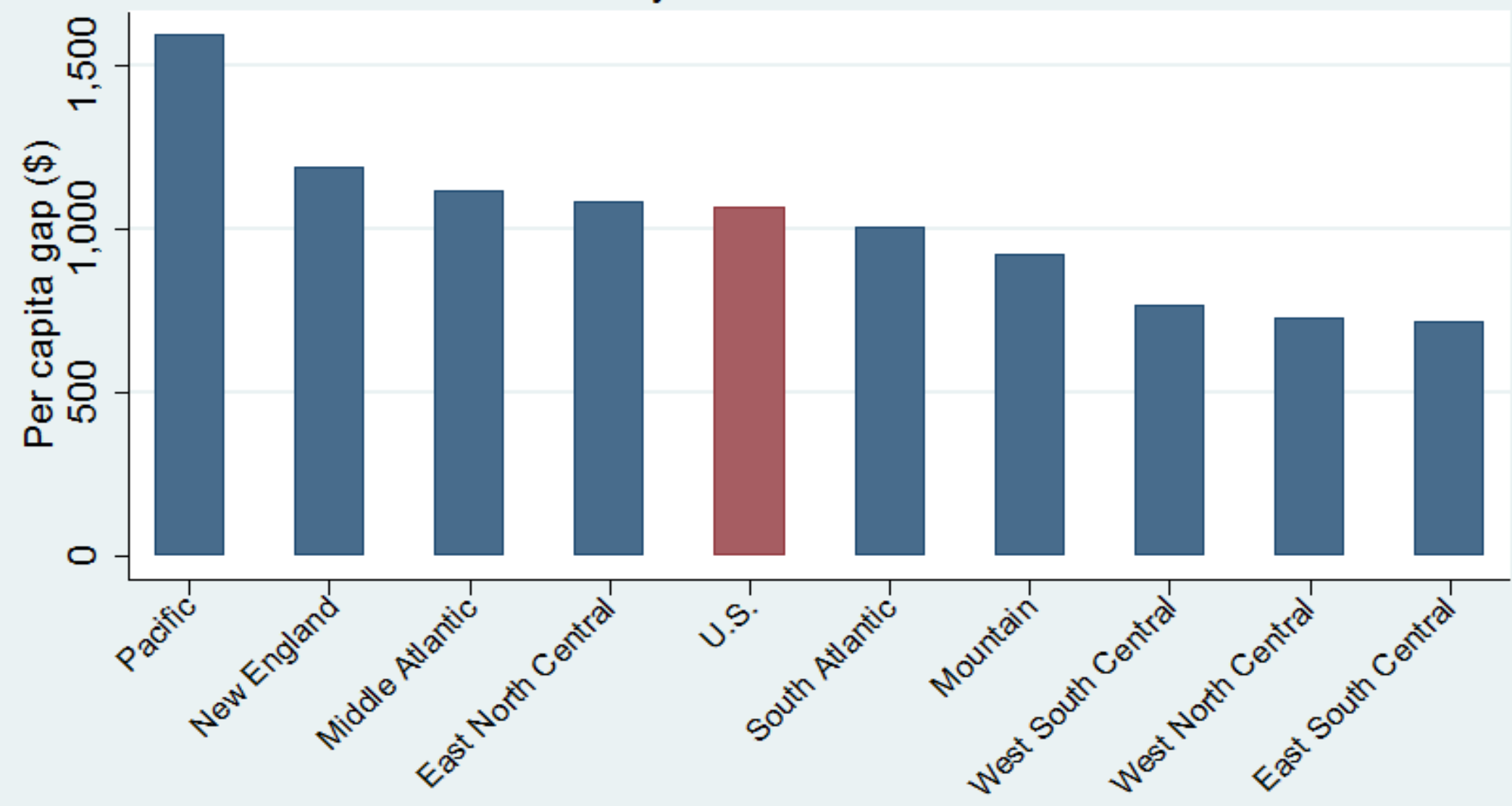

Source: Authors' calculations. 


\section{Figure 10. Disparities in State Trend Gaps Without Pension or OPEB ARCs}

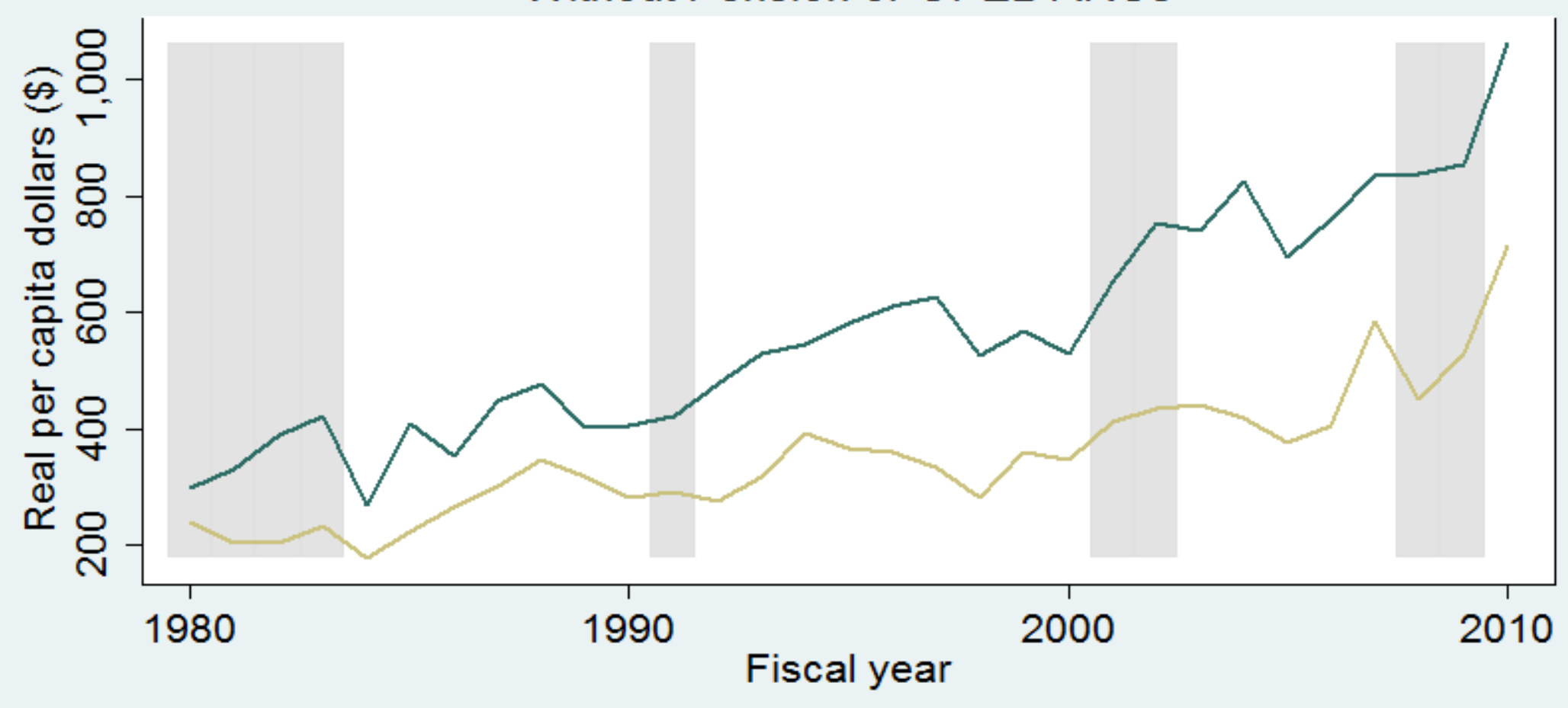

\footnotetext{
90th percentile state trend gap minus 10th percentile state trend gap 80th percentile state trend gap minus 20th percentile state trend gap Recession
}

Source: Authors' calculations. 